\title{
Impacts of cloudiness on near surface radiation and temperature in Nigeria, West Africa
}

\author{
Olaniran J. Matthew ${ }^{1} \cdot$ Muritala A. Ayoola $^{2} \cdot$ Emmanuel O. Ogolo $^{3} \cdot$ Lukman A. Sunmonu $^{2}$
}

Received: 31 March 2020 / Accepted: 25 November 2020 / Published online: 1 December 2020

(c) Springer Nature Switzerland AG 2020

\begin{abstract}
This study investigates impacts of cloudiness on surface radiation budget and temperature from 1983 to 2018 in Nigeria, West Africa. The National Aeronautics and Space Administration meteorological datasets were used to achieve this objective. Net radiation $(R)$ increased latitudinally from the coast to the inland areas. The least value of $R$ was obtained in wet season which coincided with the period when cloud cover was at its optimal. We obtained significant decreasing trends $\left(-0.110\right.$ to $-0.536 \mathrm{Wm}^{-2}$ year $\left.^{-1}\right)$ in $R$ but significant increasing trends in cloud cover in most parts of the region. Under clear-sky conditions, however, significant increasing trends $\left(0.256-0.807 \mathrm{Wm}^{-2}\right.$ year $\left.^{-1}\right)$ in $R$ were obtained. Annual mean temperature showed significant upward trends under all-sky $\left(0.009-0.059^{\circ} \mathrm{C}_{\text {year }}{ }^{-1}\right)$ and clear-sky $\left(0.019-0.072^{\circ} \mathrm{C}\right.$ year $\left.{ }^{-1}\right)$ conditions. Furthermore, significant negative correlations $(-0.70 \leq r \leq-0.95)$ were obtained between monthly values of cloud cover and $R$ over the country. However, $r$ values for cloud cover and temperature were positive over Sahel $(r \sim 0.65)$ but negative over Guinea ( $r \sim 0.45$ ); both significant at $p<0.05$. Changes in $R$ were accounted for by 21 to $26 \%$ variations in cloud cover, while fluctuation in temperature was explained by about $14 \%$ variation in cloud cover over Sahel region at $p<0.05$. Our results revealed that the surface radiation budget was significantly perturbed by variations in cloudiness which resulted in net cloud-radiative cooling $\left(-30 \mathrm{Wm}^{-2}\right)$ over Guinea but warming over Savannah $\left(25 \mathrm{Wm}^{-2}\right)$ and Sahel $\left(50 \mathrm{Wm}^{-2}\right)$ zones.
\end{abstract}

Keywords Cloudiness $\cdot$ Surface radiation budget $\cdot$ Radiative impacts $\cdot$ Temperature $\cdot$ Nigeria

\section{Introduction}

The interaction of solar radiation components with the earth's atmosphere maintains the energy balance and determines the temperature of the earth's surface $[1,2]$. Thus, observations of the modulations of the shortwave (SW) and longwave (LW) by cloud-radiative forcing could provide useful insights into the cloud-climate interaction $[3,4]$.

Fraction of the incoming solar energy reflected by Earth back into atmosphere is called Earth's planetary (surface) albedo. It is a fundamental component of the processes that govern the magnitude, distribution and variability of Earth's climate and climate change $[5,6]$. Surface albedo is highly variable, depending on many factors, such as landcover types, snow/ice cover, surface roughness or textural characteristics, mineral composition soil moisture content and human activities, such as deforestation, agriculture, irrigation, pollution and urbanization [7-12].

A linear relationship between the moisture content and surface albedo has been widely documented $[13,14]$. In agreement with this assertion, Audu et al. [15] reported higher surface albedo $(\sim 0.6)$ in wet season than $(\sim 0.4)$ in dry season over Sahel region in northern Nigeria. They

Olaniran J. Matthew, abefematt@yahoo.com | 1 Institute of Ecology and Environmental Studies, Obafemi Awolowo University, Ile-Ife, Nigeria. ${ }^{2}$ Department of Physics and Engineering Physics, Obafemi Awolowo University, lle-Ife, Nigeria. ${ }^{3}$ Department of Physics, Federal University of Technology, Akure, Nigeria. 
attributed higher albedo and lower incoming solar radiation obtained in wet season to the rain-bearing clouds which pervaded the sky in the rainy season compared to the dry season. It has also been reported that natural phenomena such as wild fire could alter surface albedo [12, 16-18].

The spatial and temporal variation of the surface net (all-wave) radiation, which is the sum of SW and LW net radiation, is responsible for the re-distribution of the available energy. For example, net radiation controls the inputs of latent and sensible heat fluxes into the atmosphere, and the oceanic heating over the ocean [12]. Radiative forcing is an externally imposed change in the radiative energy budget of the Earth's climate system [19]. The energy budget is characterized by an approximate balance between SW absorption and LW emission by the climate system [20-22]. Change in radiative forcing, which can affect either the SW or LW components of the radiative budget, can be caused by a number of factors such as variations in solar insolation, alteration in surface boundary conditions related to land use change and desertification, or natural and anthropogenic perturbations to the radiatively active species in the atmosphere known as greenhouse gases e.g. $\mathrm{CO}_{2}, \mathrm{CH}_{4}, \mathrm{~N}_{2} \mathrm{O}$ and the halocarbons [21, 23].

Furthermore, clouds and aerosols can exert a strong influence on regional radiative balance by reflecting SW radiation back to space, emitting $\mathrm{LW}$ radiation to the surface and absorbing LW radiation emitted by the warmer earth; thereby providing one of the strongest feedback pathways in the climate system [4,24-28]. Thus, changes in aerosol loading and cloud cover as well as cloud properties could cause a significant reduction in surface solar radiation [29]. In addition, because clouds interact so strongly with both SW and LW radiation, small changes in cloudiness could have a large effect on the climate system [30, 31]. Atmospheric cloud-radiative effects (CRE) describe the change in radiative heating within the atmosphere owing to clouds. The literature revealed that CRE increases with cloud cover and decreases with the solar zenith angles [32]. It has also been reported that the effects of clouds on the radiation balance at the top-of-the-atmosphere (TOA) and within the troposphere are quite different from their effect at the Earth's surface [3,33]. Clouds, on average, is found to cool the surface by reflecting $\mathrm{SW}$ radiation and warm it by increasing the downward flux of LW radiation [26]. Thus, the effect of clouds on the atmospheric energy budget, however, is found to be less straightforward [33]. Also, clouds could either warm or cool the atmosphere, depending on their vertical structure. For example, Slingo and Slingo [34] reported that low clouds can cool the atmosphere by increasing the downward emission of LW radiation, while high clouds warm it by decreasing the upward emission of LW radiation. Within deep convection in the tropics, where high clouds dominate, cloud-radiation interactions warm the upper troposphere because absorption of $\mathrm{LW}$ and $\mathrm{SW}$ radiation is much larger than the cloudy emission of $L W$ radiation $[33,35]$. Similarly, isolated low clouds were found to cause net radiative cooling of the atmosphere, which reduces the warming from other cloud types by approximately $10 \%$ [36]. The combination of these effects increases the cloud-radiative effect at the TOA. It has also been shown that perturbations to the atmospheric radiation budget, that are induced by cloud changes in response to climate forcing, dictate the eventual response of the global-mean hydrological cycle to climate forcing [24]. Hence, little changes in the cloudradiative forcing fields can play a significant role as a climate feedback mechanism [3, 33].

Several studies have investigated variations and implications of surface radiation balance on the climate of West Africa [14, 25, 37-42]. The literature revealed significant variations in seasonal patterns of net radiation over the humid tropical rainforest (i.e. Guinea zone) [9], and the Sahelian region of West Africa [41]. It has also been documented that cloud processes, level and types modulate LW and SW radiation components, which affect surface temperature and water cycle in the region [25]. During the wet season (July and August), the heavy cloud blocks the direct component of the solar irradiance resulting to the observed minimum value of daily energy over West Africa $[41,42]$. It has been shown that dust particles have a complex impact on the radiative transfer process because of their ability to interact both in shortwave and longwave radiation [29]. As such, due to the fact that West Africa is notably subject to large smoke and mineral dust loads, the regional radiative budget is found to be significantly impacted $[39,43]$. Annual cycle of radiation is also reported to have a substantial influence on the seasonal variation of the monsoon system over West Africa [44]. However, some previous studies over West Africa used radiative models to estimate radiation components, while a few others used ground measurements for just a few periods of time e.g. 1 to 24 months [37-39]. This was so because long-term data (for more than 2 years) on net radiation are still scarce for most parts of West Africa [37] due to high cost of maintenance of net radiation measurements on a continuous long-time basis $[9,45]$. Thus, availability of satellite-derived radiation data such as those provided by the National Aeronautics and Space Administration (NASA) promises to complement the paucity of these measurements, even though such data do not have the spatial or temporal resolution that in situ net radiation sensors provide. Some of these available studies revealed that cloud formation is a major source of uncertainty for future climate projections through a diversity of feedbacks 
between clouds and radiative processes in the region. In addition, dust particles during the dry Harmattan season, particularly in the West African Sahel, have been shown to have a complex impact on the radiative transfer process because of their ability to interact both in SW and LW radiation [25]. However, long-term variation in surface radiation balance and its impacts on cloudiness in different parts of West Africa is still not yet fully understood. Therefore, the present study investigates annual and seasonal variations in cloud cover from 1983 to 2018 and their impacts on the surface radiation budget and temperature over different climatic zones of Nigeria.

\section{Materials and methods}

\subsection{Study area}

Nigeria (Fig. 1) has a unique tropical climate with two prominent seasons dominated by the West African monsoon, WAM [46-48]. WAM flow produces a wet season of several months of rainfall and a dry season during which the low-level flow transports hot and dry air from the Sahara Desert into the northern Sahel [40]. The most clearly marked spatial differences in the regional climate are found between the highly humid and relatively colder zone in the south and a semi-arid region in the interior north [49].The wet season is longer in the south (April-October) than the north (May/June-September) while total annual rainfall are within the range of $1500-2000 \mathrm{~mm} /$ year and $450-600 \mathrm{~mm} /$ year in the south and north, respectively $[50,51]$. Daily temperature in the south and northern parts of the country ranges from 23 to $32^{\circ} \mathrm{C}$ and 18 to $38^{\circ} \mathrm{C}$, respectively [52]. The topography and vegetation zones are shown in Fig. 1. The topography ranges from lowland $(20-100 \mathrm{~m})$ along the Atlantic coastline areas in the south to high plateau in the central north (700-800 m) and mountains (800-1500 m) along the eastern border (Fig. 1b). The southern coastline areas are covered with mangrove forest and fresh water swamp (Fig. 1C). It is followed by rainforest in the southwestern zone, tall and short grass savannah in the central and parts of the northern zones as well as marginal savannah in the north-eastern border.
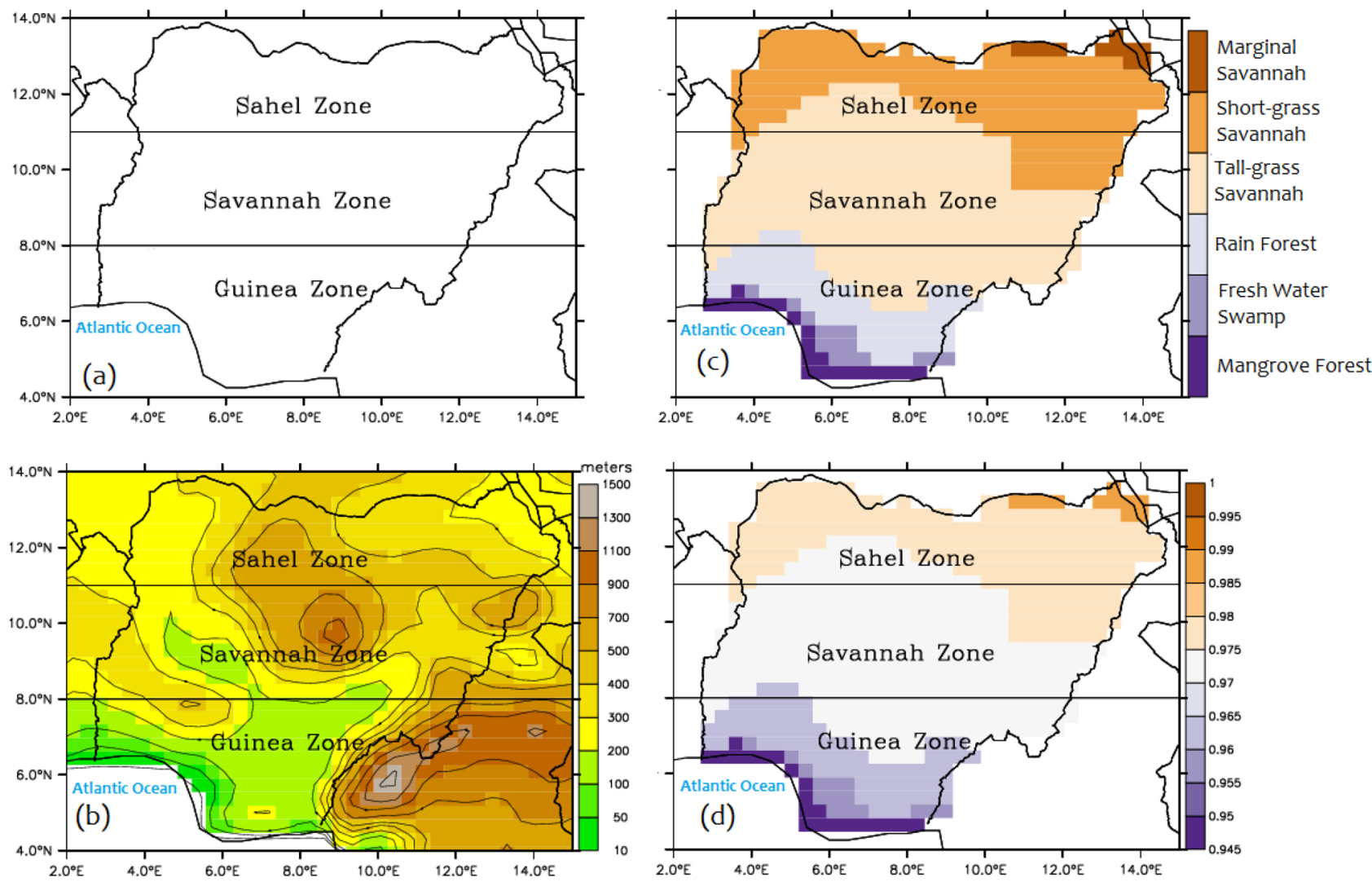

Fig. 1 Sketch map of Nigeria showing a the climatic regions designated as Guinea, Savannah and Sahel zones: b topography; c vegetation zones; and $\mathbf{d}$ surface emissivity 


\subsection{Data source}

Essentially, we analyzed monthly climatology datasets of surface radiation components, near and skin surface temperatures as well as cloud cover of the National Aeronautics and Space Administration's (NASA) Modern-Era Retrospective Analysis for Research and Applications (MERRA) for 1983-2018 period over Nigeria, West Africa (Fig. 1a). The data were obtained from the archive of the Prediction of Worldwide Energy Resource (POWER) project supported by the National Aeronautics and Space Administration (NASA) and Langley Research Center, LaRC (https ://power.larc.nasa.gov/). They are improved global meteorological datasets generated with version 5.12.4 of the Goddard Earth Observing System (GEOS) atmospheric model and data assimilation system (DAS) with spatial resolution of 0.5 degree longitude and 0.5 degree latitude $[53,54]$. The performance of NASA-MERRA data product for global solar radiation had been previously evaluated and validated over Nigeria, West Africa $[55,56]$ and other regions around the world e.g. China [57], Pakistan [58], Brazil [59] and wider areas [60]. These studies show that the datasets exhibit tolerable discrepancies compared with ground observations (and other global reanalyses) and provide scientific reference for rational use of NASA datasets in the selected regions. Consequently, the products have been widely used for climate impacts studies over different parts of the world including Nigeria, West Africa $[61,62]$.

\subsection{Methods and data processing}

Data analyses were carried out over the entire Nigerian domain $\left(4^{\circ} \mathrm{N}-14^{\circ} \mathrm{N} ; 2^{\circ} \mathrm{E}-15^{\circ} \mathrm{E}\right)$ with a special focus on three designated climatic zones (Fig. 1a) using a widely used climate classification method over West Africa based on similarities in land-use/land-cover, climate and ecosystems [48, 52]. These zones are: (1) Guinea (between latitude $4^{\circ} \mathrm{N}$ and $\left.8^{\circ} \mathrm{N}\right)$; (2) Savannah, ( $8^{\circ} \mathrm{N}$ and $11^{\circ} \mathrm{N}$ and; (3) Sahel $\left(11^{\circ} \mathrm{N}\right.$ and $14^{\circ} \mathrm{N}$ ). This classification enables us to effectively assess the contributions of cloud cover on the radiation budget over different parts of the country. The relevant NASA's MERRA datasets obtained, as provided by POWER, consist of, cloud cover fraction, surface albedo, near surface temperature (at $2 \mathrm{~m}$ ), skin surface temperature, all-sky downwelling (incoming) shortwave (SW) radiation, $R_{\mathrm{S} \downarrow}$ and longwave (LW) radiation, $R_{\mathrm{L} \downarrow}$ as well as clear-sky downwelling SW. Following the convection of signs, downwelling and upwelling radiations at the earth surface are positive and negative, respectively.

The upwelling SW radiation, $R_{\mathrm{S} \uparrow}$, under all-sky and clearsky conditions was estimated as the fraction of the corresponding $R_{\mathrm{S} \downarrow}$ that is reflected by the surface, i.e.,
$R_{\mathrm{S} \uparrow}=\alpha R_{\mathrm{S} \downarrow}$

where $a$ is the surface albedo.

The net SW radiation, $R_{S}$, under all-sky and clear-sky conditions were then estimated as:

$R_{\mathrm{S}}=R_{\mathrm{S} \downarrow}-R_{\mathrm{S} \uparrow}$

The upwelling $\mathrm{LW}$ radiation $R_{\mathrm{L} \uparrow}$ under all-sky conditions and both $R_{\mathrm{L} \downarrow}$ and $R_{\mathrm{L} \uparrow}$ under clear-sky were estimated using the Stefan-Boltzmann equation (Eq. 3) and the parameterization scheme for atmospheric emissivity (Eq. 4) proposed by Staley and Jurica [63] as widely used in the literature [64-66]. Specifically, LW radiation $R_{\mathrm{L} \uparrow}$ under all-sky and clear-sky conditions was obtained as:

$R_{\mathrm{L} \uparrow}=\sigma \varepsilon_{\mathrm{s}} T_{\mathrm{s}}^{4}$

where $\varepsilon_{\mathrm{s}}$ of the emissivity of the surface, sigma is the Stefan-Boltzmann constant $\left(5.6705 \times 10^{-8} \mathrm{~W} \mathrm{~m}^{-2} \mathrm{~K}^{-4}\right)$ and $\mathrm{T}_{\mathrm{S}}$ the skin surface temperature in kelvin under all-sky or clear-sky conditions. The country's vegetation cover classification in Fig. 1c (adapted from Abiodun et al. [52]) was used to derive spatial distribution of surface emissivity (Fig. 1d) using the values previously obtained with remotesensing technology over the region [67] and similar vegetation types elsewhere $[68,69]$.

For $R_{\mathrm{L} \downarrow}$ under clear-sky conditions, however, we used air temperature, Ta in Eq. (3) with the following expression for atmospheric emissivity, $\varepsilon_{a}[1,64]$ :

$\varepsilon_{a}=0.67 P_{\mathrm{w}}^{0.08}$

where $P_{\mathrm{w}}$ is the partial water pressure/actual vapor pressure in hectopascal expressed as a function of relative humidity, $\mathrm{RH}(\%)$ and temperature [70, 71]:

$P_{\mathrm{W}}=6.1078 \exp \left(\frac{17.27 T_{a}}{273.3+T_{a}}\right) \times \mathrm{RH} / 100$

Then, the net $\mathrm{LW}$ radiation, $R_{\mathrm{L}}$ and net (all-wave) radiation, $R$, are given in Eqs. (6) and (7):

$R_{\mathrm{L}}=R_{\mathrm{L} \downarrow}-R_{\mathrm{L} \uparrow}$

$R=R_{\mathrm{S}}-R_{\mathrm{L}}$

Cloud-radiative effects for shortwave $\left(\mathrm{CRE}_{\mathrm{SW}}\right)$ and longwave $\left(C R E_{L W}\right)$ were estimated as $[3,26,30]$ :

$$
\begin{aligned}
& \mathrm{CRE}_{\mathrm{SW}}=\left(R_{\mathrm{S} \uparrow}-R_{\mathrm{S} \downarrow}\right)_{\text {clear - sky }}-\left[R_{\mathrm{S} \uparrow}-R_{\mathrm{S} \downarrow}\right]_{\text {all - sky }} \\
& \mathrm{CRE}_{\mathrm{LW}}=\left(R_{\mathrm{L} \uparrow}-R_{\mathrm{L} \downarrow}\right)_{\text {clear - sky }}-\left[R_{\mathrm{L} \uparrow}-R_{\mathrm{L} \downarrow}\right]_{\text {all - sky }}
\end{aligned}
$$

\section{SN Applied Sciences}


The values of $C R E_{S W}$ and $C R E_{L W}$ provide measure of the impacts of clouds on SW and LW radiation, respectivelywhere positive $C_{\mathrm{SE}}$ or $\mathrm{CRE}_{\mathrm{LW}}$ means heating effect and their negative values indicate cooling effect.

Then, the net radiative effects CRE was computed as:

$$
\mathrm{CRE}=\mathrm{CRE}_{\mathrm{sw}}+\mathrm{CRE}_{\mathrm{LW}}
$$

Analysis of inter-annual and seasonal variations in surface radiation budget, temperature and cloud cover was obtained, and the results were presented and discussed. For all the years (1983-2018), the standardized anomaly, $\varphi$, was calculated as:

$\varphi=\frac{x-\bar{x}}{\sigma}$

where $x$ is the actual value of each parameters (radiation components, temperature and cloud cover), $\bar{x}$ is their longterm means and $\sigma$ the standard deviations.

We adopted a least-square-fit and Mann-Kendall, MK test $[72,73]$ to investigate the magnitudes and significance of the annual trends of all the parameters at $99 \%(0.1), 95 \%$ (0.05) and 90\% (0.01) confidence levels. The MK statistics, as fully described in the literature $[51,74,75]$, is a nonparametric trend test which is often used to test for trends in climatological-data time series. In addition, correlations between all monthly mean values (1983-2018) of cloud cover and radiation components as well as temperature were computed, while a linear regression analysis was performed to determine the contributions of cloudiness (independent variable) to surface radiation budget and temperature.

\section{Results and discussion}

\subsection{Annual mean variations in surface radiation budget and temperature}

Figure 2 depicts the long-term annual mean (1983-2018) spatial variations in both upwelling and downwelling radiation components under all-sky condition over Nigeria. By sign conventions, positive and negative signs denote downwelling and upwelling radiation components, respectively. Downwelling SW $\left(R_{\mathrm{S} \downarrow}\right)$ and LW $\left(R_{\mathrm{L} \downarrow}\right)$ radiation were about 200 and $410 \mathrm{Wm}^{-2}$ over the Guinea zone, respectively (Fig. 2a, b). Their estimates over Sahel were $270 \mathrm{Wm}^{-2}\left(R_{\mathrm{S} \downarrow}\right)$ and $375 \mathrm{Wm}^{-2}\left(R_{\mathrm{L} \downarrow}\right)$. Results, thus, revealed that $R_{\mathrm{S} \downarrow}$ increased inland from the coast, while $R_{\mathrm{L} \downarrow}$ decreased inland. This could be explained by spatial distribution of cloud cover which decreases inland from the coast. Our results further confirm previous findings that $R_{\mathrm{S} \downarrow}$ over West Africa increases latitudinally from the coast
$[55,76]$. The upwelling SW $\left(R_{\mathrm{S} \uparrow}\right)$ and $\mathrm{LW}\left(R_{\mathrm{L} \uparrow}\right)$ radiation were -35 and $-440 \mathrm{Wm}^{-2}$ over Guinea, respectively, while $R_{\mathrm{S} \uparrow} \approx-90 \mathrm{Wm}^{-2}$ and $R_{\mathrm{L} \uparrow} \approx-460 \mathrm{Wm}^{-2}$ over Sahel (Fig. $2 \mathrm{c}$, d). Net SW $\left(R_{\mathrm{S}}\right)$ and LW $\left(R_{\mathrm{L}}\right)$ radiation were about 150 and $-20 \mathrm{Wm}^{-2}$ over Guinea, respectively (Fig. 2e, f). However, the values of $R_{\mathrm{S}}\left(\approx 180 \mathrm{Wm}^{-2}\right)$ and $R_{\mathrm{L}}\left(\approx-170 \mathrm{Wm}^{-2}\right)$ were higher in both Sahel and Savannah than in the Guinea (130 and $40 \mathrm{Wm}^{-2}$, respectively). The values obtained were within the range of values previously reported in literature $[9,77]$. Furthermore, annual mean variations in $R_{\mathrm{S}}$ and $R_{\mathrm{L}}$ radiation components under clear-sky are shown in Fig. 3. As expected, $R_{\mathrm{S}}$ radiation components under clearsky were generally higher in magnitudes than their values under all-sky condition while those of $R_{\mathrm{L}}$ components were reverse [78]. Over the country, $R_{\mathrm{S} \downarrow}$ ranged between $255 \mathrm{Wm}^{-2}$ (in Guinea) and $290 \mathrm{Wm}^{-2}$ (Sahel) while $R_{\mathrm{St}}$ ranged between $-40 \mathrm{Wm}^{-2}$ (Guinea) and $-100 \mathrm{Wm}^{-2}$ (Sahel) (Fig. 3a, b). Under clear-sky condition, $R_{L \downarrow}$ were $395 \mathrm{Wm}^{-2}$ over Guinea and $365 \mathrm{Wm}^{-2}$ over Sahel while $R_{\mathrm{L} \uparrow}$ were -445 and $-470 \mathrm{Wm}^{-2}$ over Guinea and Sahel, respectively (Fig. 3c, d).

The net (all-wave) radiation, $R$, were about $180 \mathrm{Wm}^{-2}$ over Guinea, $240 \mathrm{Wm}^{-2}$ over Savannah and $280 \mathrm{Wm}^{-2}$ over Sahel (Fig. 4a). This demonstrated that $R$ generally increases with increasing latitude. Cloud cover fraction were about $80 \%$ over Guinea, $50 \%$ over Savannah and $45 \%$ over Sahel (Fig. 4b). Surface albedo and temperature were $0.20: 25.0^{\circ} \mathrm{C}$ over Guinea and $0.30: 28.0^{\circ} \mathrm{C}$ over Sahel, respectively (Fig. 4c, d). Observed spatial distribution of $R$ over the country suggested higher surface heating in the semi-arid regions (Savannah and Sahel) than in the Guinea. Similar spatial variations in $R$ have been reported in the analysis of net radiation data over West Africa by Ojo [79] and Hayward and Oguntoyinbo [80]. These results supported the fact that $R$ is highly dependent on geographical location, time of the day, season, cloud cover, surface temperature, and type and conditions of the surface as indicated by albedo and emissivity $[81,82]$. Increased $R_{\mathrm{S} \downarrow}$ and $R$ with increasing latitude have been attributed to the observed spatial pattern of cloud cover [76]. Different levels and categories of cloud have been found to reduce $R_{\mathrm{S} \downarrow}$ significantly in the tropics [25]. Thus, future changes in cloudiness and atmospheric aerosols could have significant impacts on surface temperature and the rate of evapotranspiration, with important consequences on atmosphere-surface interactions and the regional hydrological cycle as speculated by Bouniol et al. [25]. In addition, we found that the potential of the ground surface to reflect $R_{\mathrm{S} \downarrow}$ is higher in the Sahel region as remonstrated by the spatial distribution of surface albedo in Fig. 4c. This supports higher $R_{\mathrm{S} \uparrow}$ recorded in Sahel compared to the Guinea zone in the south. Variations in cloudiness have been found to significantly modulate the 

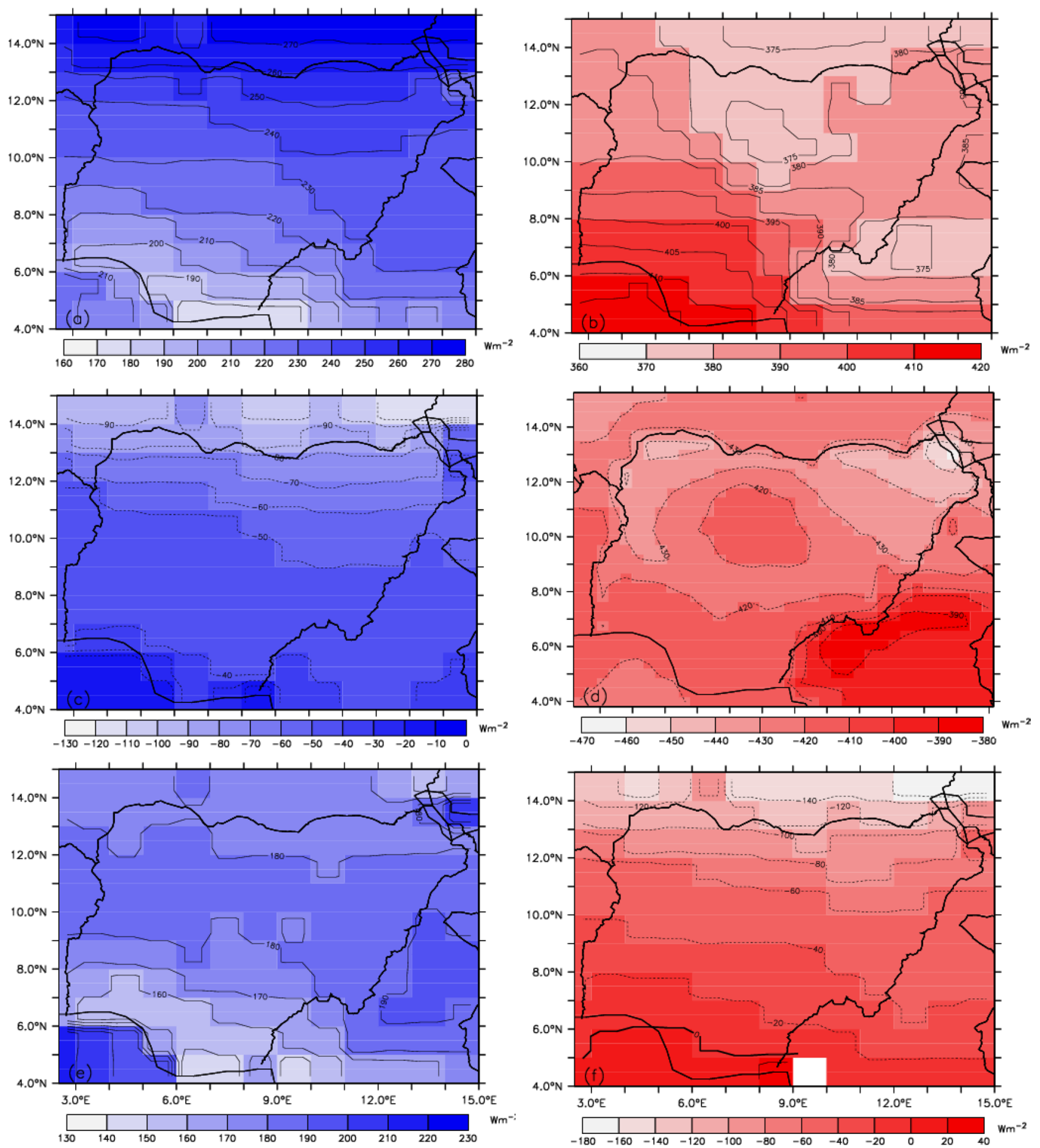

Fig. 2 Annual means of all-sky over Nigeria (1983-2018): a downwelling shortwave radiation, $R_{\mathrm{S}\rfloor}$ b downwelling LW radiation, $R_{\mathrm{L}\rfloor} \mathbf{c}$ upwelling SW radiation, $R_{\mathrm{S} \uparrow} \mathbf{d}$ upwelling $\mathrm{LW}, R_{\mathrm{L} \uparrow}$ e net $\mathrm{SW}$ radiation,

atmospheric emissivity, temperature distribution and the general circulation of the atmosphere which are the most important regulators of the Earth's climate [14, 83]. Thus, potential future variations in cloud cover and radiation

$R_{\mathrm{S}}$ and $\mathbf{f}$ net $\mathrm{LW}$ radiation, $R_{\mathrm{L}}$. By convection, positive and negative signs denote downwelling and upwelling radiation components, respectively

budget over the country could have significant impact on the regional climate. Moreover, the observed pattern of cloud cover produced lower $R_{\mathrm{S} \downarrow}\left(\sim 200 \mathrm{Wm}^{-2}\right)$ in Guinea than $\left(\sim 265 \mathrm{Wm}^{-2}\right)$ Sahel but higher $R_{\mathrm{L \downarrow}}\left(\sim 400 \mathrm{Wm}^{-2}\right)$ over 

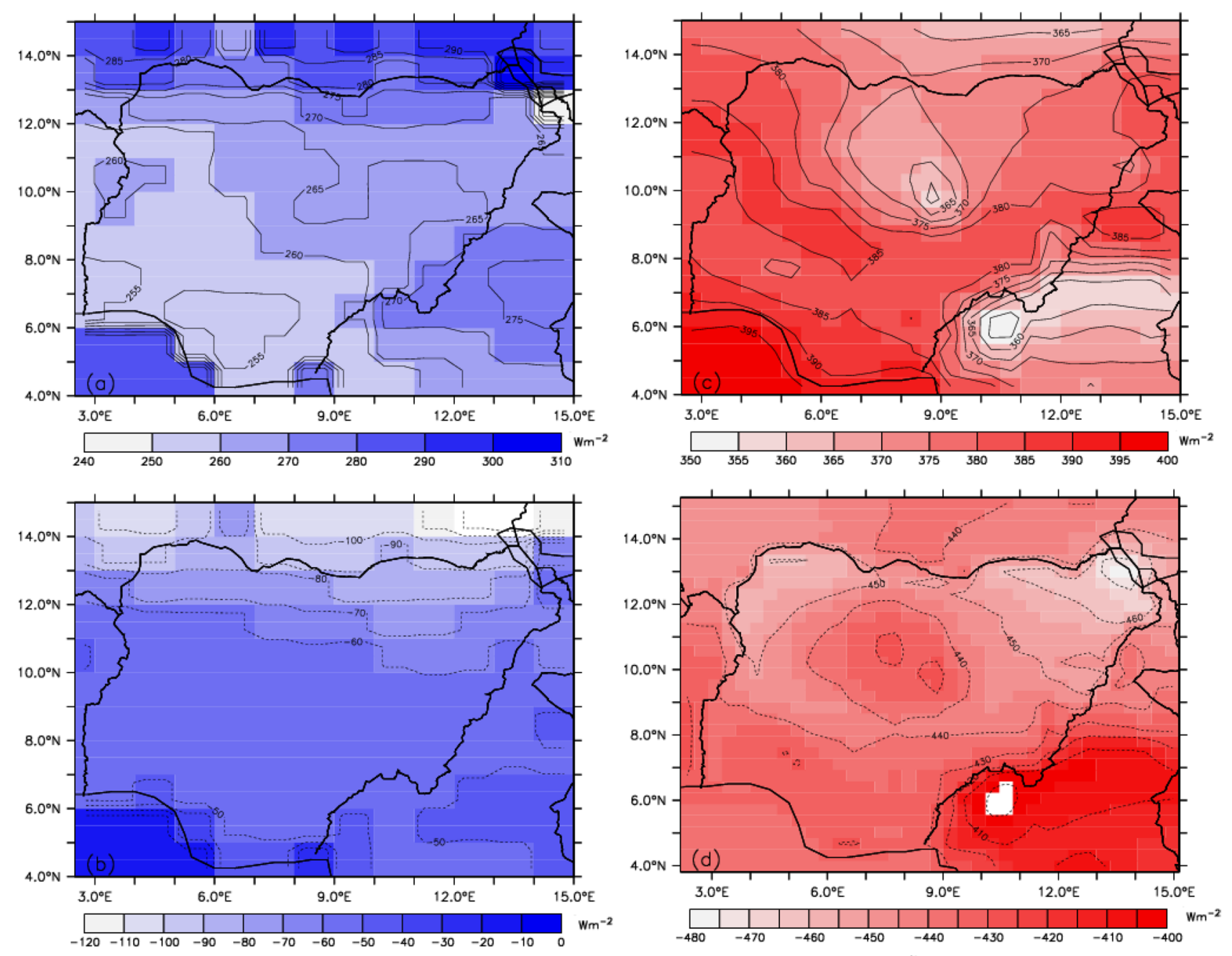

Fig. 3 Annual means of clear-sky over Nigeria (1983-2018): a downwelling SW radiation, $R_{\mathrm{S} \downarrow}$ b upwelling SW radiation, $R_{\mathrm{S} \uparrow} \mathbf{c}$ downwelling $\mathrm{LW}$ radiation, $R_{\mathrm{L} \downarrow}$ and $\mathbf{d}$ upwelling $\mathrm{LW}$ radiation, $R_{\mathrm{L} \uparrow}$. By

convection, positive and negative signs denote downwelling and upwelling radiation components, respectively

Guinea than $\left(\sim 380 \mathrm{Wm}^{-2}\right)$ Sahel. This is a signal that higher cloud cover fraction enhances $R_{\mathrm{L} \downarrow}[30]$. Higher temperature obtained in Sahel could be attributed to higher $R$ recorded in the zone. However, surface temperature in Guinea is moderated by cool monsoon air from the Atlantic Ocean (known as the West African Monsoon, WAM) and the presence of thick vegetation in the region $[52,55,84]$ which significantly reduces warming effects of enhanced $R_{\mathrm{L} \downarrow}$ over the region.

\subsection{Inter-annual variations and trends}

Figures 5 and 6 represent the inter-annual variations (in terms of standardized anomaly) and the trend lines of the four radiation components under all-sky and clear-sky conditions, respectively. Results suggested high spatial and temporal inter-annual variability in radiation components

over the country during the study period (1983-2018). For example, both $R_{\mathrm{S} \downarrow}$ and $R_{\mathrm{S} \uparrow}$ had more of negative anomalies, while positive anomalies were predominant for $R_{\mathrm{L} \downarrow}$ and $R_{\mathrm{L} \uparrow}$ under all-sky condition in all the three climatic zones (Fig. 5). However, all the four radiation components under clear-sky showed positive anomalies (Fig. 6). The anomalies obtained for all the radiation components under both sky conditions ranged between -2.2 and 2.2 .

Summary of results of all the trend analysis is presented in Table 1. The positive values of MK statistics indicate upward trend line, while the negative values show the downward trend at $p=0.01,0.05$, and 0.10 confidence levels. Results revealed decreasing trends in $R_{\mathrm{S} \downarrow}$ (Guinea $=-0.268 \mathrm{Wm}^{-2}$ year ${ }^{-1}$, Savannah $=-0.207 \mathrm{Wm}^{-2}$ year $^{-1}$ and Sahel $=-0.116 \mathrm{Wm}^{-2}$ year $^{-1}$ ) and $R_{\mathrm{S} \uparrow}$ (Guinea $=-0.218 \mathrm{Wm}^{-2}$ year $^{-1}$, Savannah $=-0.165 \mathrm{Wm}^{-2}$ year $^{-1}$ and Sahel $=-0.084 \mathrm{Wm}^{-2}$ year $^{-1}$ ) 

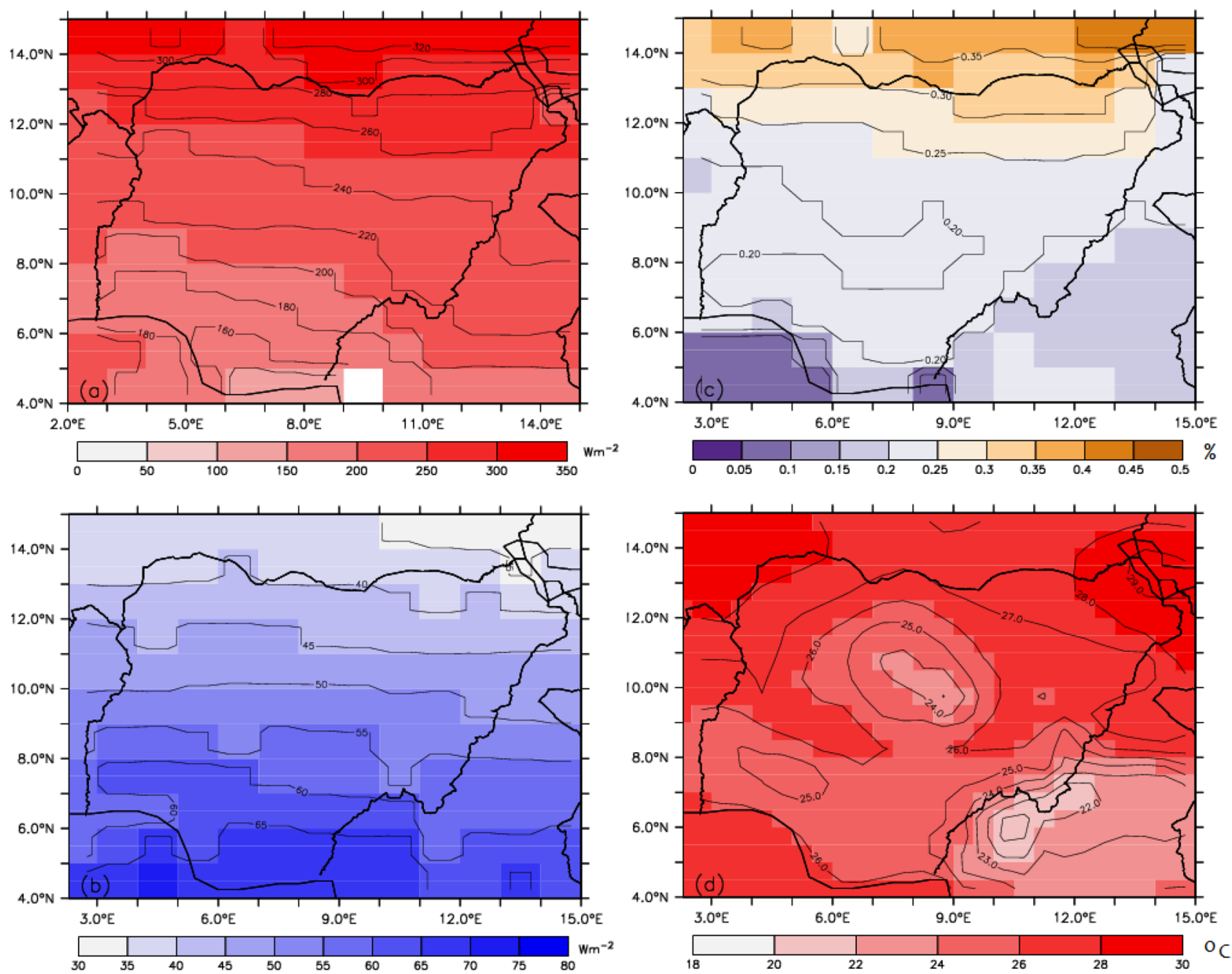

Fig. 4 Spatial distribution of annual means of a net (all-wave) radiation, $R\left(\mathrm{Wm}^{-2}\right)$, b cloud cover fraction (\%), c surface albedo (dimensionless), and $\mathbf{d}$ near surface temperature $\left({ }^{\circ} \mathrm{C}\right)$ over Nigeria (1983-2018)

under all-sky conditions (Table 1). These trends in SW radiation components were found to be significant except in the Sahel zone. Results further indicated that there have been statistically significant increases in $R_{\mathrm{L} \downarrow}$ (Guinea $=0.585$, Savannah $=0.257$ and Sahel $=0.215$ ) and $R_{\mathrm{L} \uparrow}$ (Savannah $=0.422$ and Sahel $\left.=0.124\right)$. However, the upward trend of $R_{\mathrm{L} \uparrow}(0.018)$ over Guinea was found to be insignificant. Consequently, decreasing trends $(-0.110$ to $-0.536 \mathrm{Wm}^{-2}$ year $^{-1}$ ) in $R$ were obtained under all-sky in all the zones. Cloud cover showed significant increasing trends over Guinea $\left(0.473 \%\right.$ year $\left.^{-1}\right)$ and Sahel $(0.081 \%$ year $\left.{ }^{-1}\right)$, but decreasing and insignificant trend was obtained over Savannah $\left(-0.026 \%\right.$ year $\left.^{-1}\right)$. On the other hand, all the four radiation components showed increasing trends (0.114-0.559 $\mathrm{Wm}^{-2}$ year $\left.{ }^{-} 1\right)$ under clear-sky conditions in all the zones (Table 1). These changes were found to be significant except the trend of $R_{\mathrm{L} \uparrow}\left(0.017 \mathrm{Wm}^{-2}\right.$ year $^{-1}$ ) obtained over the Guinea zone. Significant upward trends in $R\left(0.256-0.807 \mathrm{Wm}^{-2}\right.$ year $\left.^{-1}\right)$ were estimated over all zones, contrary to downward trends obtained under allsky condition. Results showed significant upward trends in temperature under all-sky $\left(0.009-0.059^{\circ} \mathrm{C} \mathrm{year}^{-1}\right)$ and clear-sky $\left(0.019-0.072^{\circ} \mathrm{C}_{\text { year }}{ }^{-1}\right)$ conditions over the entire region. In brief, results of the 36-year trend analysis suggested warmer climate over the entire country, in agreement with the previous studies $[48,52]$ and demonstrated that the surface radiation and temperature had been significantly perturbed due to changes in cloud-radiative forcing as speculated in the literature [e.g. 3, 21, 23-36].

\subsection{Seasonal mean variations}

Variations in seasonal or annual cycle of surface radiation balance in different designated climatic zones of Nigeria are illustrated in Fig. 7. The lowest $\left(157 \mathrm{Wm}^{-2}\right.$ (Guinea), $181 \mathrm{Wm}^{-2}$ (Savannah) and $220 \mathrm{Wm}^{-2}$ (Sahel)) 

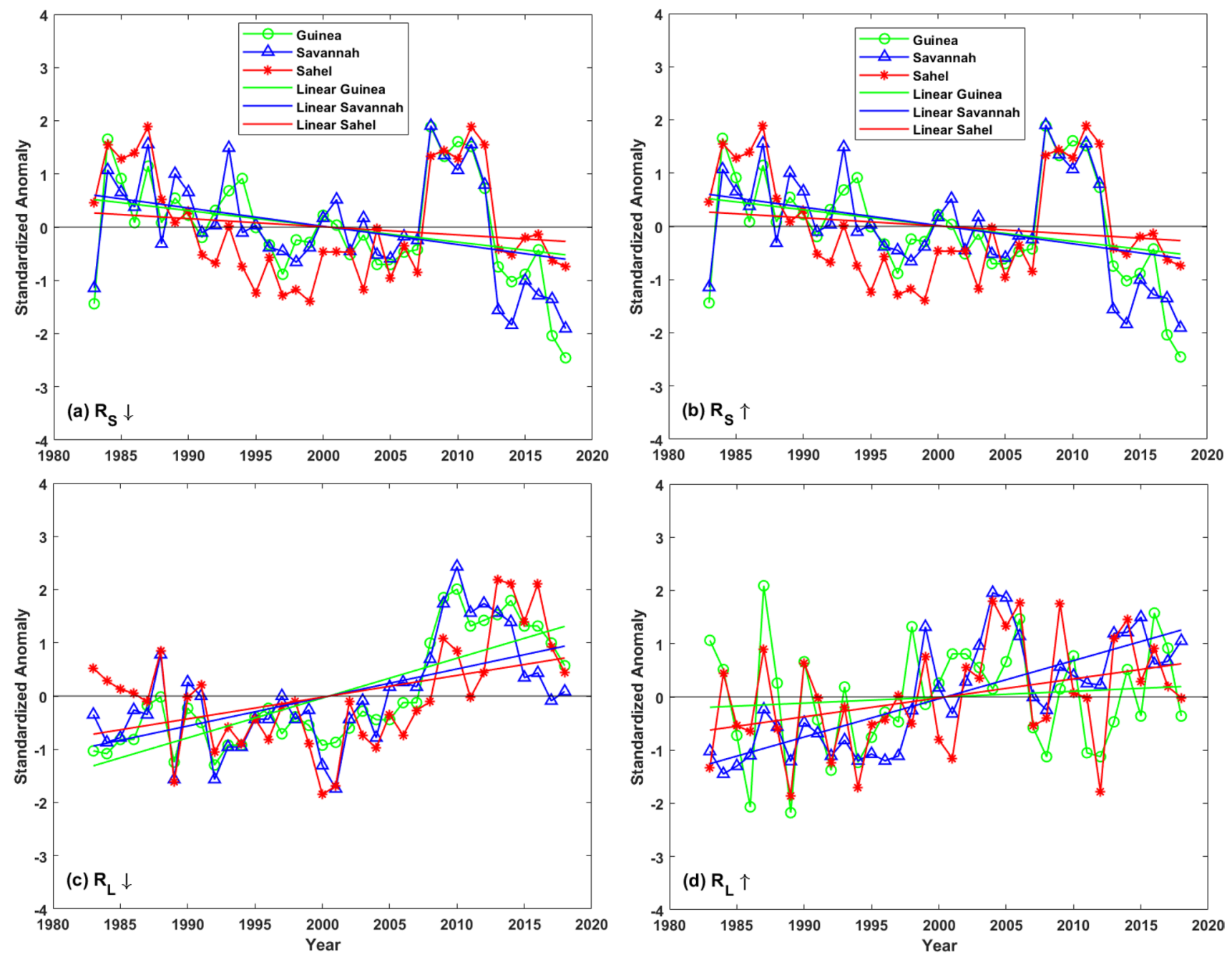

Fig. 5 Inter-annual variability (standardized anomaly) in radiation components under all-sky conditions over Guinea, Savannah, and Sahel regions of Nigeria (1983-2018): a downwelling SW, $R_{\mathrm{S} \downarrow}$ b upwelling SW, $R_{\mathrm{S} \uparrow}$ c downwelling $\mathrm{LW}, R_{\mathrm{L} \downarrow}$ and $\mathbf{d}$ upwelling $\mathrm{LW}$ radiations, $R_{\mathrm{L} \uparrow}$

and the peak (231 $\mathrm{Wm}^{-2}$ (Guinea), $260 \mathrm{Wm}^{-2}$ (Savannah) and $282 \mathrm{Wm}^{-2}$ (Sahel)) of $R_{\mathrm{S} \downarrow}$ occurred in July/August and February/April over the country, respectively (Fig. 7a). $R_{\mathrm{S} \uparrow}$ was generally lower than $R_{\mathrm{S} \downarrow}$ and recorded its lowest $\left(-60 \mathrm{Wm}^{-2}\right.$ (Guinea), $-70 \mathrm{Wm}^{-2}$ (Savannah) and $-86 \mathrm{Wm}^{-2}$ (Sahel)) and the highest $\left(-70 \mathrm{Wm}^{-2}\right.$ (Guinea), $-83 \mathrm{Wm}^{-2}$ (Savannah) and $-115 \mathrm{Wm}^{-2}$ (Sahel)) in August and March/April, respectively (Fig. 7c). In brief, the highest values of $R_{\mathrm{S} \downarrow}$ and $R_{\mathrm{S} \uparrow}$ were obtained in late dry season (February-March in Guinea; April-May in Savannah and Sahel) and the least in the wet season (July-August) over the country. Seasonal pattern of $R_{L \downarrow}$ was opposite to the $R_{\mathrm{S}}$ components with the peak in dry season and the lowest in the wet. This might not be unconnected with the cloud-radiative impact. Higher cloud cover during the wet season increases the atmospheric emissivity and thus enhances $R_{\mathrm{LL}}$. Observed spatial pattern and magnitudes of $R_{\mathrm{L} \uparrow}$ followed that of temperature (with the highest over the north) as explained by the Stefan-Boltzmann Eq. (3).

Figure 8 shows the seasonal variations in net radiation $(R)$, cloud cover, surface albedo and temperature. Results showed that $R$ had the least values $\left(100,121\right.$ and $171 \mathrm{Wm}^{-2}$ over Guinea, Savannah and Sahel, respectively) in the peak of the wet season and the highest $\left(245 \mathrm{Wm}^{-2}\right.$ (Guinea), $310 \mathrm{Wm}^{-2}$ (Savannah and Sahel)) in dry season (Fig. 8a). The peak of cloud cover (79\% (Guinea), 80\% (Savannah, and $66 \%$ (Sahel)) occurred in wet season (August-September), while the least (38\% (Guinea), 22\% (Savannah, and $21 \%$ (Sahel)) were recorded in the dry period (January-March) (Fig. 8b). Seasonal variations in surface albedo were similar in Guinea and Savannah zones with the peak (0.22 (Guinea) and 0.28 (Savannah)) and the lowest values (0.17 (Guinea) and 0.18 (Savannah)) in wet and dry seasons, respectively. In contrast, the maximum (0.29) and the least $(0.25)$ surface albedo were obtained in dry and 

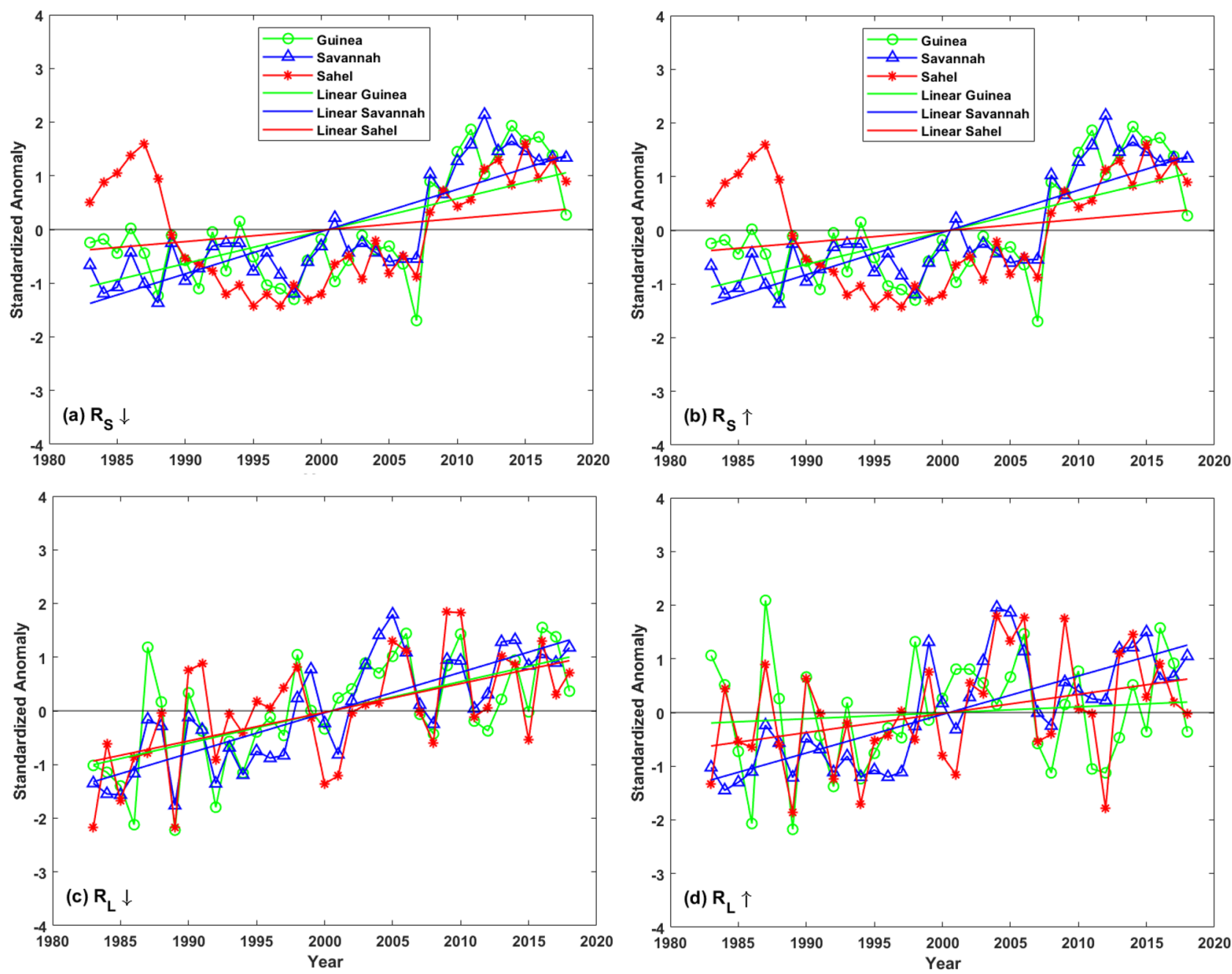

Fig. 6 Inter-annual variability (standardized anomaly) in radiation components under clear-sky conditions over Guinea, Savannah, and Sahel regions of Nigeria (1983-2018): a downwelling SW, $R_{\mathrm{S} \downarrow} \mathbf{b}$ upwelling SW, $R_{\mathrm{S} \uparrow}$ c downwelling $\mathrm{LW}, R_{\mathrm{L} \downarrow}$ and $\mathbf{d}$ upwelling $\mathrm{LW}$ radiations, $R_{\mathrm{L} \uparrow}$

wet seasons, respectively (Fig. 6c). Similarly, the highest $\left(26.9{ }^{\circ} \mathrm{C}\right.$ (Guinea), $28.3^{\circ} \mathrm{C}$ (Savannah, and $31.2^{\circ} \mathrm{C}$ (Sahel)) and the least $\left(24.4^{\circ} \mathrm{C}\right.$ (Guinea), $23.4{ }^{\circ} \mathrm{C}$ (Savannah, and $22.1^{\circ} \mathrm{C}$ (Sahel)) temperatures were recorded in dry and wet seasons. These are indications that the entire country is warmer in dry season than the wet. Results support the fact that cooling effect during the monsoon season is mainly due to the dominance of $R_{\mathrm{S}}$ in the net cloudradiative forcing [25]. Higher cloudiness during the wet (monsoon) season could be attributed to lower $R$ values recorded during this season [85]. In addition, the results in agreements with the literature $[7,13,14,86]$ suggested that higher albedo during the wet season was due to rise is soil moisture. Over Sahel, however, the least in surface albedo occurred in wet season (i.e., September) and highest in the dry (March). This could be as a results of combined effects of surface cover type, color, surface roughness or textural characteristics, mineral composition and organic matter more than the soil moisture content in the region. However, this is at variant with the findings of Audu et al. [15] where albedo estimate over a location in the Sahel region was reported to be higher in wet season (September) than dry season. The reasons for this disparity could not be ascertained. However, the reason could be attributed to the latent error in (NASA's MERRA) satellite surface measurements due to interference of high atmospheric aerosol and Harmattan dust in West African Sahel during the dry season.

\subsection{Relationship between cloudiness, surface radiation budget and temperature}

The relationship between cloud cover and radiation budget components as well as temperature is shown in Fig. 9. The results indicated significant negative correlations $(r \sim-0.80$ at $p \leq 0.05)$ between cloud cover and $R_{\mathrm{S} \downarrow}$ 


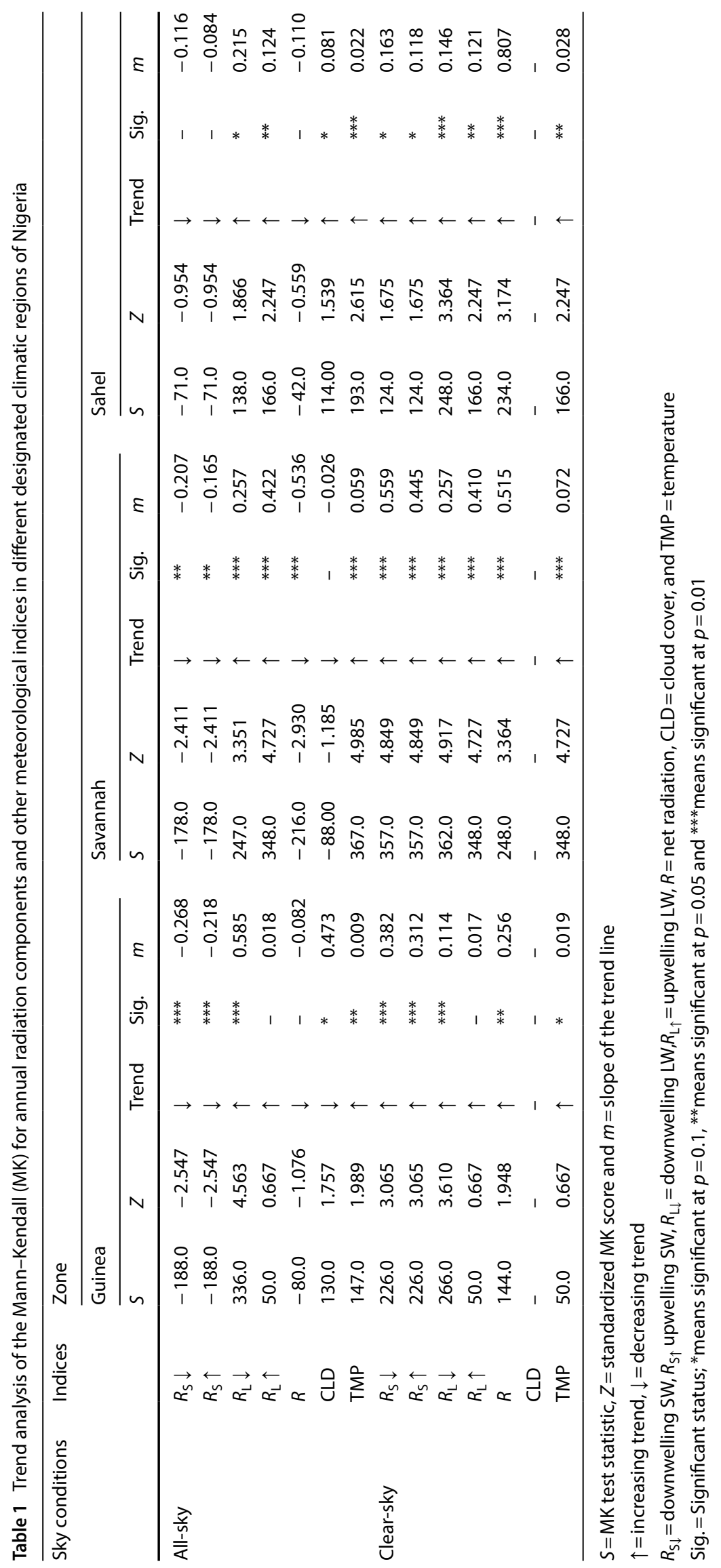



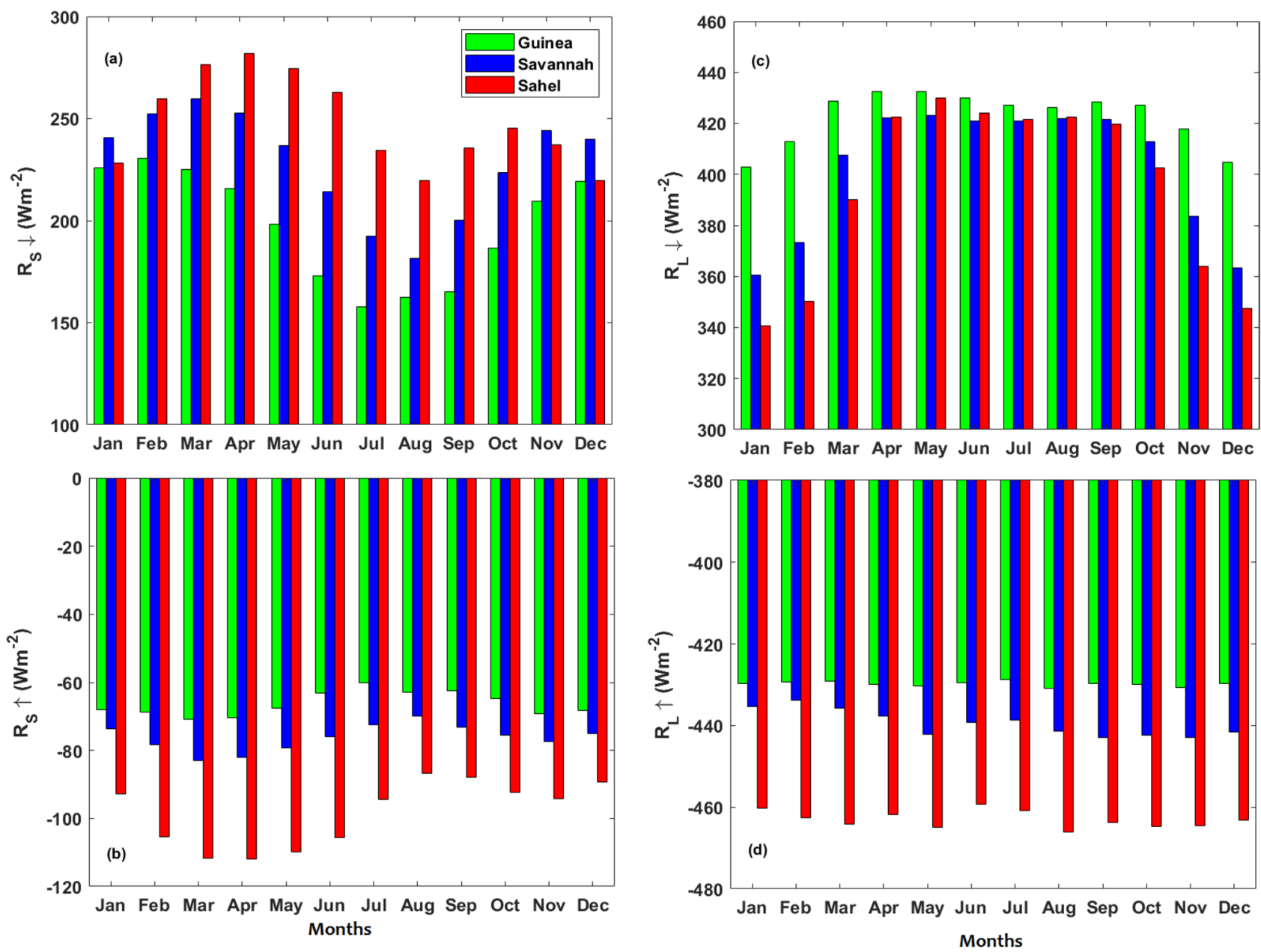

Fig. 7 Monthly mean variations in radiation components over Guinea, Savannah, and Sahel regions of Nigeria (1983-2018): a downwelling SW, $R_{\mathrm{S} \downarrow}$ b upwelling SW, $R_{\mathrm{S} \uparrow}$ c downwelling $\mathrm{LW}, R_{\mathrm{L} \downarrow}$ and

over Guinea and Savannah zones but positive and insignificant $(r \leq 0.40)$ over most parts of the Sahel (Fig. 9a). In addition, cloud cover showed positive and significant correlation ( $r \sim 0.60)$ with $R_{\mathrm{S} \uparrow}$ over Guinea, while the positive correlations $(r \leq 0.40)$ obtained over most parts of Savannah and Sahel were insignificant (Fig. 9b). The correlations between cloud cover and $R_{\mathrm{L} \downarrow}$ were generally high, positive and significant $(0.90 \leq r \leq 0.99)$ over the entire country (Fig. 9c). However, $R_{\mathrm{L} \uparrow}$ produced negative and significant $(-0.90 \leq r \leq-0.99)$ correlations with cloud cover over the entire country (Fig. 9d). These are indications that increased cloud cover fraction enhances $R_{L \downarrow}$ but inhibits $R_{\mathrm{L} \uparrow}$. As expected, net all-wave radiation, $R$ exhibited significant negative correlations $(-0.70 \leq r \leq-0.95)$ with cloud cover over the entire country (Fig. 9e). The interpretation is that, future increase in cloudiness could lead to decrease in surface net radiation. However, $r$ values obtained for cloud cover and temperature were generally negative over Guinea $(r \sim-0.45)$ but positive over most

d upwelling LW radiations, $R_{\mathrm{L} \uparrow}$. By convection, positive and negative signs denote downwelling and upwelling radiation components, respectively

parts of Savannah and Sahel $(r \sim 0.65)$; all significant at $p<0.05$ (Fig. 9f). It suggests that the higher the cloud cover the more the surface cooling (i.e., lower temperature) over Guinea but more warming over the semi-arid regions. The result is a clear signal that cloudiness plays a major role in modulating surface radiation budget and temperature over the country.

\subsection{Impacts of cloudiness on surface radiation budget and temperature}

Table 2 gives the summary of regression analysis carried out to describe the contribution of cloudiness to surface radiation balance and temperature. The total variance explained by cloud cover (i.e., its contribution) to net all-wave radiation were found to be $23.9 \%$ (Guinea), $25.8 \%$ (Savannah) and 21.0\% (Sahel); all significant at $p<0.05$ (Table 2). In addition, cloud cover had significant impacts (20-33\%) on all the four radiation components 

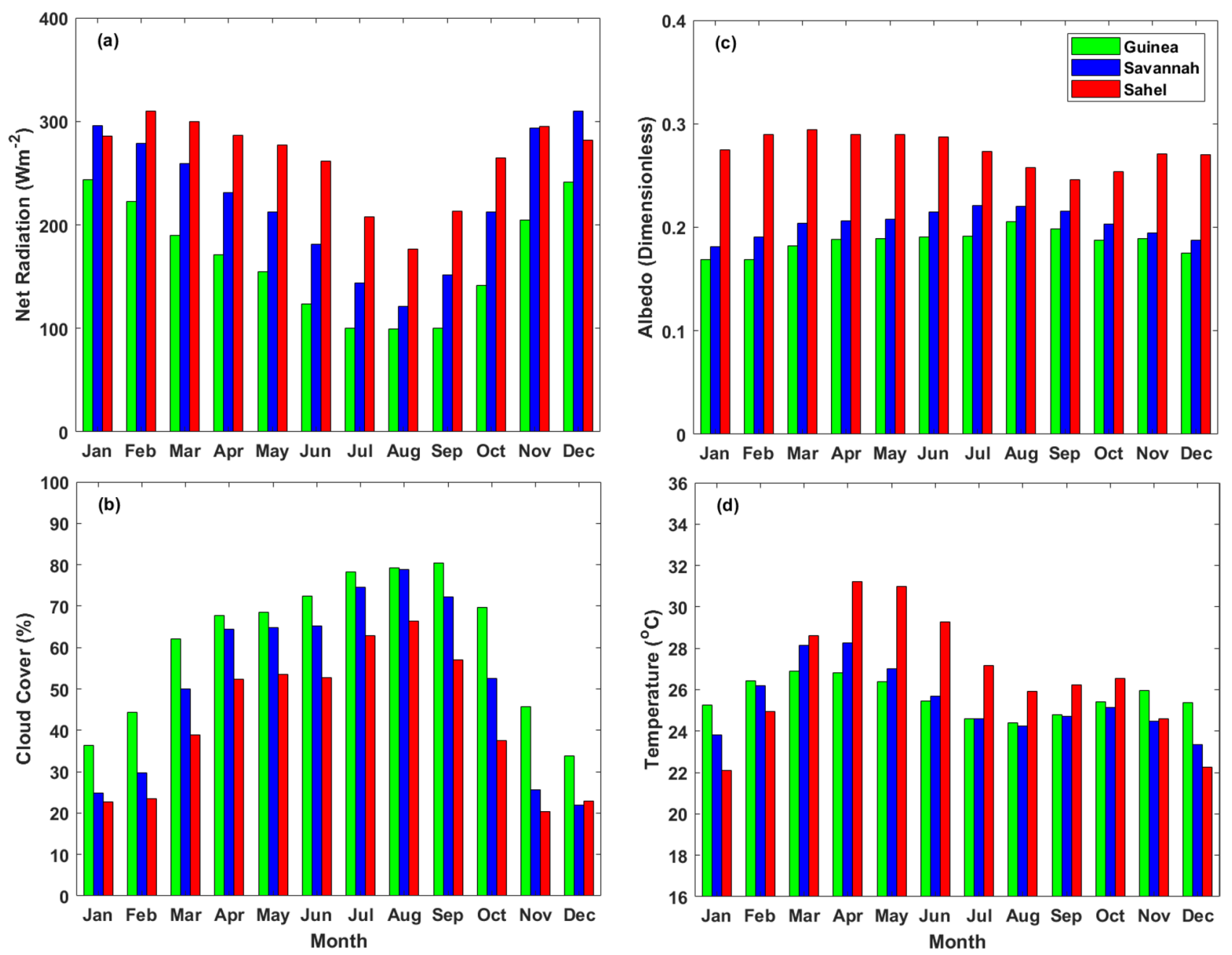

Fig. 8 Monthly mean variations (mean and standard deviation, STD) of a net radiation, $R \mathbf{b}$ cloud cover fraction, $\mathbf{c}$ albedo, and $\mathbf{d}$ near surface temperature over Guinea, Savannah, and Sahel regions of Nigeria (1983-2018)

in the country except for both $R_{\mathrm{S} \uparrow}$ and $R_{\mathrm{S} \downarrow}$ over Sahel and $R_{\mathrm{S} \uparrow}$ over Savannah. The total variance explained by cloud cover to variation in temperature were 2.3\% (Guinea), 2.0\% (Savannah) and $13.8 \%$ (Sahel). The changes in temperature accounted for by $13.8 \%$ variation in the predictor (cloud cover) over Sahel was found to be significant at $p<0.05$. This suggested that cloud cover had insignificant impacts on temperature over Guinea and Savannah. This could be attributed to the influence of WAM and forest on warming reduction over the region as reported in previous studies $[52,84]$.

Figure 10 explains cloud-radiative effects (CRE) in $R_{S}$ (tagged $C R E_{S W}$ ) and $R_{\mathrm{L}}$ (tagged $\mathrm{CRE}_{\mathrm{LW}}$ ) radiation over Nigeria. Negative CRE means cooling effects, while positive indicates warming. Generally, the estimated $C R E_{S W}$ was negative (Fig. 10a), while $\mathrm{CRE}_{\mathrm{LW}}$ was positive (Fig. 10b) over the entire country. It suggested cloud-radiative cooling effect of $R_{\mathrm{S}}$ which decreased latitudinally from the coast to continental areas and heating effect of $R_{\mathrm{L}}$ which showed increment from the coast to the continental areas. For example, estimated $\mathrm{CRE}_{S W}$ were $-55 \mathrm{Wm}^{-2}$ (Guinea), $-30 \mathrm{Wm}^{-2}$ (Savannah) and $-10 \mathrm{Wm}^{-2}$ (Sahel), while CRE $\mathrm{LW}_{\mathrm{LW}}$ were 25,45 and $65 \mathrm{Wm}^{-2}$ in Guinea, Savannah and Sahel zones, respectively. The heating effect of $C R E_{L W}$ in the northern parts of the country was completely neutralized by cooling effect of $C R E_{S W}$ to produce a net surface warming (positive CRE) over the zones $\left(25 \mathrm{Wm}^{-2}\right.$ in Savannah and $50 \mathrm{Wm}^{-2}$ in Sahel; Fig. 10c). Miller et al. [40] have also reported similar pattern of net cloud-radiative effects over the West African Sahel. The resultant heating effects of CRE in Sahel could be attributed to the enhanced $R_{\mathrm{L} \uparrow}$ due to higher surface temperature triggered by higher incoming solar radiation and overall drier and less cloudy atmosphere compared to Guinea zone [83]. However, heating effect of $C R E_{L W}$ in the coastal areas was not strong enough to neutralize the cooling effect of $C R E_{S W}$ and thus 

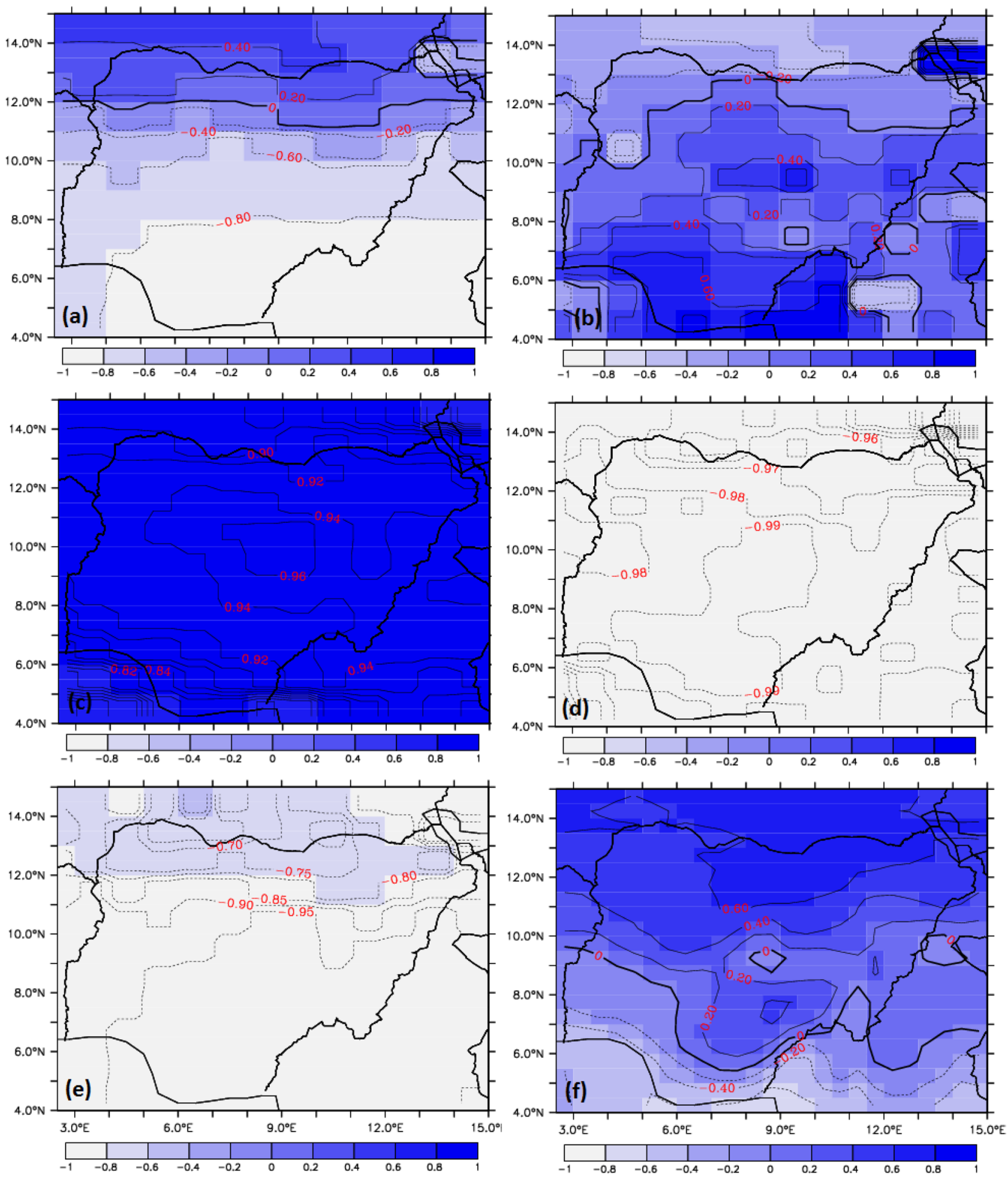

Fig. 9 Correlation coefficients, $r$ between cloudiness and a downwelling SW, $R_{\mathrm{S} \downarrow} \mathbf{b}$ upwelling $\mathrm{SW}, R_{\mathrm{S} \uparrow} \mathbf{c}$ downwelling LW, $R_{\mathrm{L} \downarrow} \mathbf{d}$ upwelling LW, $R_{\mathrm{L} \uparrow}$ e net radiation, $R$, and $\mathbf{f}$ near surface temperature

a net cooling cloud-radiative effect was obtained over the region $\left(-30 \mathrm{Wm}^{-2}\right.$; Fig. 10c). These patterns of results and the range of values obtained are in agreement with those reported in Henderson et al. [26] and Wild et al. [87]. Finally, our findings demonstrated that the surface radiation budget and temperature over the country were 
Table 2 Results of linear regression models of monthly time series of cloudiness (as an independent or explanatory variable), surface radiation components and temperature in different designated climatic regions of Nigeria

\begin{tabular}{|c|c|c|c|c|c|c|c|}
\hline \multirow[t]{2}{*}{ Zone } & \multirow[t]{2}{*}{ Regression parameter } & \multicolumn{6}{|c|}{ Dependent variable } \\
\hline & & $R_{\mathrm{S} \downarrow}$ & $R_{\mathrm{S} \uparrow}$ & $R_{\mathrm{L \downarrow}}$ & $R_{\mathrm{L} \uparrow}$ & $R$ & $T$ \\
\hline \multirow[t]{4}{*}{ Guinea } & Regression coefficient & $-1.325^{*}$ & $0.135^{*}$ & $0.547^{*}$ & $-2.463^{*}$ & $-0.074^{*}$ & -0.015 \\
\hline & Standard error & 0.288 & 0.050 & 0.090 & 0.095 & 0.006 & 0.015 \\
\hline & $\begin{array}{l}\text { 95\% Confidence Interval } \\
\text { (lower, upper) }\end{array}$ & $-1.343,-1.306$ & $0.132,0.139$ & $0.541,0.553$ & $-2.470,-2.457$ & $-0.075,-0.074$ & $-0.016,-0.014$ \\
\hline & Total variance explained & 0.174 & 0.109 & 0.201 & 0.251 & 0.239 & 0.023 \\
\hline \multirow[t]{4}{*}{ Savannah } & Regression coefficient & $-0.829^{*}$ & 0.039 & $1.117^{*}$ & $-3.214^{*}$ & $-0.069^{*}$ & 0.020 \\
\hline & Standard error & 0.279 & 0.057 & 0.120 & 0.146 & 0.007 & 0.023 \\
\hline & $\begin{array}{l}\text { 95\% Confidence Interval } \\
\text { (upper, lower) }\end{array}$ & $-0.847,-0.811$ & $0.035,0.043$ & $1.109,1.125$ & $-3.223,-3.205$ & $-0.070,-0.069$ & $0.019,0.022$ \\
\hline & Total variance explained & 0.135 & 0.013 & 0.258 & 0.281 & 0.258 & 0.020 \\
\hline \multirow[t]{4}{*}{ Sahel } & Regression coefficient & 0.164 & -0.016 & $1.898^{*}$ & $-3.962^{*}$ & $-0.046^{*}$ & $0.111^{*}$ \\
\hline & Standard error & 0.412 & 0.179 & 0.233 & 0.266 & 0.011 & 0.043 \\
\hline & $\begin{array}{l}\text { 95\% Confidence Interval } \\
\text { (upper, lower) }\end{array}$ & $0.138,0.191$ & $-0.028,-0.005$ & $1.883,1.913$ & $-3.980,-3.945$ & $-0.047,-0.045$ & $0.108,0.114$ \\
\hline & Total variance explained & 0.006 & 0.000 & 0.300 & 0.331 & 0.210 & 0.138 \\
\hline
\end{tabular}

$R_{\mathrm{S} \downarrow}=$ Downwelling shortwave radiation; $R_{\mathrm{S} \uparrow}=$ Upwelling shortwave radiation

$R_{\mathrm{L \downarrow}}=$ Downwelling longwave radiation; $R_{\mathrm{L} \uparrow}=$ Upwelling longwave radiation

$R=$ Net (all-wave) radiation; $T=$ surface temperature

*Significant at $p<0.05$

significantly impacted by changes in cloudiness due to cloud-radiative effects $[36,88,89]$.

\section{Conclusion}

This study has investigated the impacts of cloudiness on near surface radiation and temperature in Nigeria, West Africa. To achieve this objective, it used the Modern-Era Retrospective Analysis for Research and Applications (MERRA) datasets sponsored by the National Aeronautics and Space Administration (NASA). Our findings revealed that:

1. Downwelling shortwave $(\mathrm{SW})$ radiation $\left(R_{\mathrm{S} \downarrow}\right)$, upwelling longwave $(\mathrm{LW})$ radiation $\left(R_{\mathrm{L} \uparrow}\right)$, net (allwave) radiation and temperature increased latitudinally from the coast to inland or continental areas. However, cloud cover and downwelling LW radiations $\left(R_{\mathrm{L} \downarrow}\right)$ were found to decrease inland from the coast.

2. Inter-annual and seasonal changes in cloud cover, temperature and the radiation budget components varied significantly across the three designated climate zones (i.e., Guinea, Savannah and Sahel).

3. Under all-sky conditions, significant decreasing trends in $R_{S \downarrow}\left(-0.207\right.$ to $-0.268 \mathrm{Wm}^{-2}$ year $\left.^{-1}\right)$ and
$R_{\mathrm{S} \uparrow}\left(-0.165\right.$ to $-0.218 \mathrm{Wm}^{-2}$ year $\left.^{-1}\right)$ were obtained in most parts of the country. However, results indicated that there have been statistically significant increases in $R_{\mathrm{L} \downarrow}\left(0.257-0.585 \mathrm{Wm}^{-2}\right.$ year $\left.^{-1}\right)$ and $R_{\mathrm{L} \uparrow}$ (0.124-0.422 $\mathrm{Wm}^{-2}$ year $^{-1}$ ) during the study period. In addition, significant decreasing trends ( -0.110 to $-0.536 \mathrm{Wm}^{-2}$ year $^{-1}$ ) in $R$ but significant increasing trends in cloud cover were obtained in most parts of the country.

4. Under clear-sky conditions, however, all the four radiation components showed increasing trends $\left(0.114-0.559 \mathrm{Wm}^{-2}\right.$ year $\left.^{-1}\right)$ in most parts of the country while $R$ indicated significant increasing $R$ trends $\left(0.256-0.807 \mathrm{Wm}^{-2}\right.$ year $\left.^{-1}\right)$ in all zones.

5. The annual trends of temperature under all-sky (0.009-0.059 $\left.{ }^{\circ} \mathrm{C}_{\text {year }}{ }^{-1}\right)$ and clear-sky (0.019$0.072{ }^{\circ} \mathrm{C}$ year $^{-1}$ ) conditions were observed to have increased significantly over the entire region.

6. The relationship between monthly average values of cloud cover and net radiation was negative and significant at $p<0.05$ over the entire country. However, relationship between cloud cover and temperature was significant and negative over Guinea but positive over most parts of Savannah and Sahel.

7. Furthermore, changes in LW radiation components and net radiation were accounted for by 20 to $33 \%$ 
Fig. 10 Cloud-radiative effects (CRE) in a SW, CRE $\mathrm{SW}_{\mathbf{b}} \mathbf{b} \mathrm{LW}$, $\mathrm{CRE}_{\mathrm{LW}}$ and $\mathrm{c}$ net $\mathrm{CRE}$ over Nigeria (1983-2018)
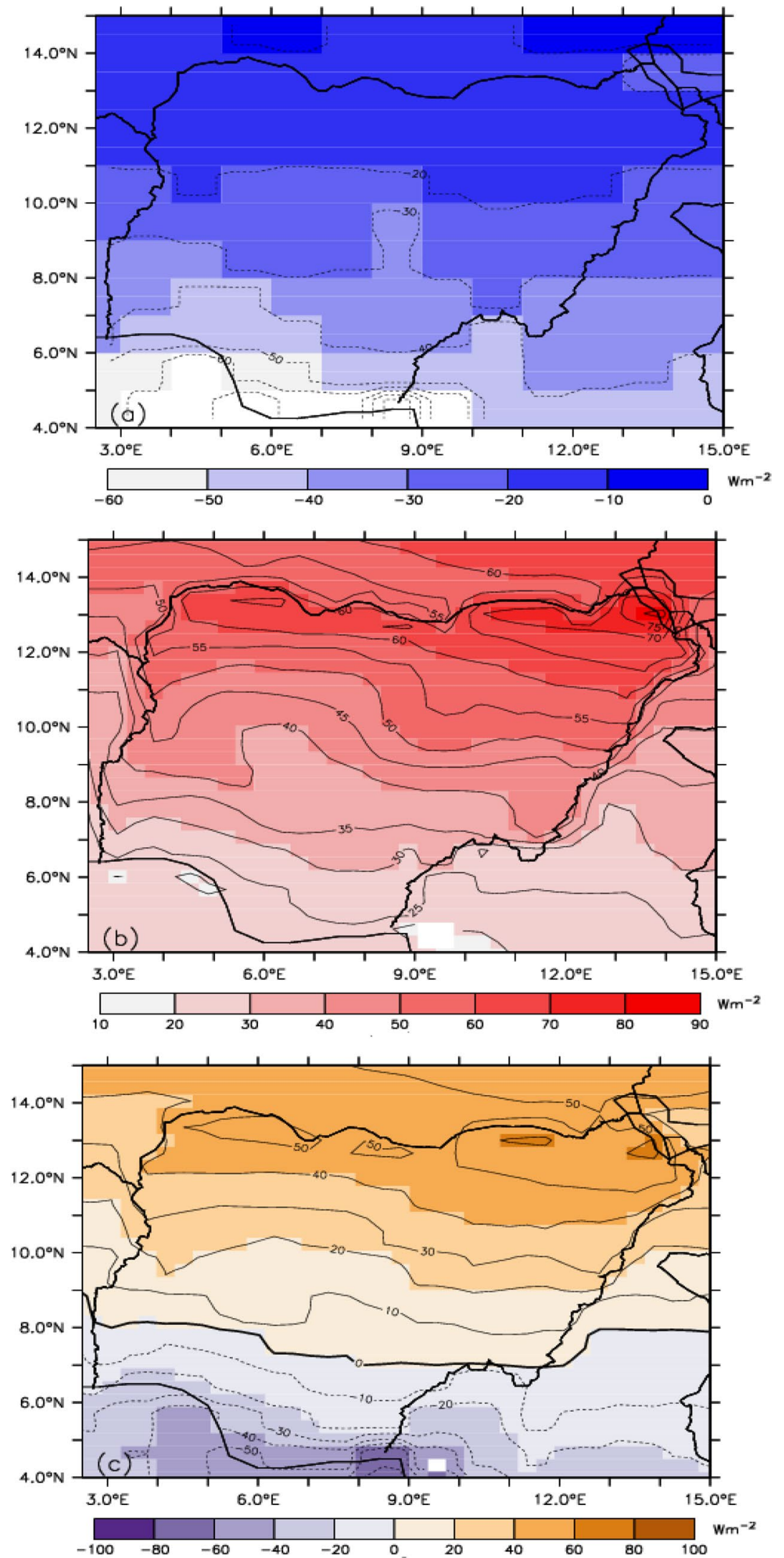
variations in cloud cover and the contributions were found to be significant across the zones.

8. Cloud-radiative cooling effect of $S W$ radiation $\left(\mathrm{CRE}_{\mathrm{SW}}\right)$ decreased latitudinally from the coast to inland areas, while the cloud-radiative heating effect of LW radiation $\left(C R E_{L W}\right)$ increased inland from the coast. Furthermore, the heating effect of $C R E_{L W}$ in the Savannah and Sahel zones was completely defused by cooling effect of $\mathrm{CRE}_{\mathrm{SW}}$ to produce a net surface warming $\left(25 \mathrm{Wm}^{-2}\right.$ (Savannah) and $50 \mathrm{Wm}^{-2}$ (Sahel)). In the Guinea zone, however, a net cooling cloud-radiative effect $\left(-30 \mathrm{Wm}^{-2}\right)$ was obtained.

9. We concluded that the surface radiation budget and temperature were significantly impacted by variations in cloudiness over the country.

10. The study has implications for improved understanding of the role of clouds in moderating the surface radiation budget and temperature in different climatic zones of Nigeria, West Africa.

11. Presumably, the uncertainties in the NASA's MERRA reanalysis due to its relatively coarse resolution could limit the utility of the datasets for this research. Thus, further work is necessary to confirm the findings of this present study using high-resolution reanalyses and ground station observations of surface solar radiation components.

Acknowledgements The authors are indebted to the National Aeronautics and Space Administration (NASA) and the collaborating Institutions and Agencies under the Prediction of Worldwide Energy Resource (POWER) project for providing the climatological datasets used in this study.

\section{Compliance with ethical standards}

Conflict of interest The authors declare that they have no competing interests.

\section{References}

1. Zhao D, Aili A, Zhai Y, Xu S, Tan G, Yin X, Yang R (2019) Radiative sky cooling: fundamental principles, materials, and applications. Appl Phys Rev 6:021306. https://doi.org/10.1063/1.5087281

2. Delgado-Bonal A, Marshak A, Yang Y, Holdaway D (2020) Analyzing changes in the complexity of climate in the last four decades using MERRA-2 radiation data. Sci Rep 10:922. https://doi. org/10.1038/s41598-020-57917-8

3. Ramanathan V, Cess R, Harisson E, Minnis P, Barkstrom B, Ahmad A, Hartmann D (1989) Cloud-radiative forcing and climate: results from the earth radiation budget experiment. Science 243:57-63

4. Collow ABM, Miller MA (2016) The seasonal cycle of the radiation budget and cloud radiative effect in the Amazon rain forest of Brazil. J Clim 29:7703-7722. https://doi.org/10.1175/ JCLI-D-16-0089.1
5. Stephens GL, O'Brien D, Webster PJ, Pilewski P, Kato S, Li JL (2015) The albedo of Earth. Rev Geophys 53:141-163

6. Zhou C, Zelinka MD, Klein SA (2016) Impact of decadal cloud variations on the Earth/'s energy budget. Nat Geosci 9:871-874. https://doi.org/10.1038/ngeo2828

7. Allen SJ, Wallance JS, Gash JHC, Savakumar MVK (1994) Measurement of albedo variation over natural vegetation. Int J Climatol $14: 625-636$

8. Stull RB (2012) An introduction to boundary layer meteorology, vol 13. Atmospheric and Oceanographic Sciences Library, Berlin

9. Ayoola MA, Sunmonu LA, Bashiru MI, Jegede OO (2014) Measurements of net all-wave radiation at a tropical location, lle-Ife, Nigeria. Atmósfera 27(3):305-315

10. Hu YH, Jia GS, Pohl C, Zhang XX, van Genderen J (2016) Assessing surface albedo change and its induced radiation budget under rapid urbanization with Landsat and GLASS data. Theor Appl Climatol 123:711-722

11. Houspanossian J, Gimenez R, Jobbagy E, Nosetto M (2017) Surface albedo raise in the South American Chaco: combined effects of deforestation and agricultural changes. Agric For Meteorol 232:118-127

12. Liang S, Wang D, He T, Yu Y (2019) Remote sensing of earth's energy budget: synthesis and review. Int J Digit Earth 12(7):737780. https://doi.org/10.1080/17538947.2019.1597189

13. Ten-Berge HFM (1990) Heat and water transfer in bare top soil and the lower atmosphere. Simulation monographs, vol 33. Pudoc Wageningen, Wageningen, p 207

14. Pyrina M, Hatzianastassiou N, Matsoukas C, Fotiadi A, Papadimas CD, Pavlakis KG, Vardavas I (2013) Cloud effects on the solar and thermal radiation budgets of the Mediterranean basin. Atmos Res. https://doi.org/10.1016/j.atmosres.2013.11.009

15. Audu MO, Isikwue BC, Eweh JE (2014) Estimation of seasonal and annual albedo of the earth's atmosphere over Kano, Nigeria. IOSR J Appl Phys 5(6):56-62

16. He T, Liang S, Wang D, Shi Q, Tao X (2014) Estimation of highresolution land surface shortwave albedo from AVIRIS data. IEEE J Appl Earth Observ Remote Sens 7:4919-4928

17. Chen X, Liang S, Cao Y, He T, Wang D (2015) Observed contrast changes in snow cover phenology in northern middle and high latitudes from 2001 to 2014. Sci Rep 5:16820

18. Chen D, Loboda TV, He T, Zhang Y, Liang S (2018) Strong cooling induced by stand-replacing fires through albedo in Siberian larch forests. Sci Rep 8:4821

19. Intergovernmental Panel on Climate Change (IPCC) (2001) Climate change 2001. In: Houghton JT et al (eds) The scientific basis. Cambridge University Press, New York, p 944

20. Kiehl JT, Trenberth KE (1997) Earth's annual global mean energy budget. Bull Am Meteorol Soc 78:197-208

21. Collins W, Ramaswamy V, Schwarzkopf MD, Sun Y, Portmann RW, Fu Q, Casanova SEB, Dufresne J-L et al (2006) Radiative forcing by well-mixed greenhouse gases: estimates from climate models in the intergovernmental panel on climate change (IPCC) fourth assessment report (AR4). J Geophys Res 111(D14):D14317

22. Soneye OO, Ayoola MA, Ajao IA, Jegede OO (2019) Diurnal and seasonal variations of the incoming solar radiation flux at a tropical station, Ile-Ife, Nigeria. Heliyon 5(5):e01673.7. https:// doi.org/10.1016/j.heliyon.2019.e01673

23. Ceppi P, Brient F, Zelinka MD, Hartmann DL (2017) Cloud feedback mechanisms and their representation in global climate models. WIREs Clim Change. https://doi.org/10.1002/wcc.465

24. Stephens GL (2005) Cloud feedbacks in the climate system: a critical review. J Clim 18:237-273

25. Bouniol D, Couvreux F, Kamsu-Tamo P-H, Leplay M, Guichard F, Favot $F$ (2012) Diurnal and seasonal cycles of cloud occurrences, types, and radiative impact over West Africa. J Appl Meteorol Climatol 51:534-553. https://doi.org/10.1175/JAMC-D-11-051.1 
26. Henderson DS, L'Ecuyer T, Stephens G, Partain P, Sekiguchi M (2013) A multi-sensor perspective on the radiative impacts of clouds and aerosols. J Appl Meteorol Climatol 52:53-871. https://doi.org/10.1175/jamc-d-12-025.1

27. Yamasoe MA, do Rosário NME, Barros KM (2017) Downward solar global irradiance at the surface in São Paulo city-the climatological effects of aerosol and clouds. J Geophys Res Atmos 122:391-404. https://doi.org/10.1002/2016JD025585

28. Jia R, Luo M, Liu YZ, Zhu QZ, Hua S, Wu CQ, Shao TB (2019) Anthropogenic aerosol pollution over the eastern slope of the Tibetan Plateau. Adv Atmos Sci 36(8):847-862. https:// doi.org/10.1007/s00376-019-8212-0

29. Soni VK, Pandithurai G, Pai DS (2012) Evaluation of long-term changes of solar radiation in India during clear day, cloudy day, foggy day and dust day. Int J Climatol 32:540-551

30. Hang Y (2016) The effect of cloud type on earth's energy balance. A thesis submitted in partial fulfilment of the requirements for the degree of Master of Science (Atmospheric and Oceanic Sciences) at the University of Wisconsin-Madison. $p$ 137

31. Yeo H, Park S-J, Kim B-M, Shiobara M, Kim S-W, Kwon H, Kim J-H, Jeong J-H, Park SS, Choi T (2018) The observed relationship of cloud to surface longwave radiation and air temperature at Ny-Ålesund, Svalbard. Tellus B Chem Phys Meteorol 70:1450589. https://doi.org/10.1080/16000889.2018.1450589

32. Tzoumanikas P, Nikitidou E, Bais AF, Andreas Kazantzidis A (2016) The effect of clouds on surface solar irradiance, based on data from an all-sky imaging system. Renew Energy 95:314-322. https://doi.org/10.1016/j.renene.2016.04.026

33. Harrop BE, Hartmann DL (2016) The role of cloud radiative heating in determining the location of the ITCZ in Aquaplanet simulations. J Clim 29:2741-2763

34. Slingo A, Slingo JM (1988) The response of a general circulation model to cloud longwave radiative forcing. I: introduction and initial experiments. Q J R Meteorol Soc 114(482):1027-1062

35. Slingo JM, Slingo A (1991) The response of a general circulation model to cloud longwave radiative forcing. Il: further studies. Q J R Meteorol Soc 117(498):333-364

36. Hill PG, Allan RP, Chiu JC, Bodas-Salcedo A, Knippertz P (2018) Quantifying the contribution of different cloud types to the radiation budget in Southern West Africa. J Clim 31:5273-5291. https://doi.org/10.1175/JCLI-D-17-0586.1

37. Jegede OO (1997) Daily averages of net radiation measured at Osu, Nigeria in 1995. Int J Climatatol 17:1357-1367

38. Jegede $\mathrm{OO}$ (2002) Observations of daytime surface energy balance in cloudy tropical conditions at lle-Ife, Nigeria. MAUSAM 53(3):359-366

39. Mallet $M$, Tulet $P$, Sercxa D, Solmon F, Dubovik G, Pelon J, Pont $V$, Thouron $O$ (2009) Impact of dust aerosols on the radiative budget, surface heat fluxes, heating rate profiles and convective activity over West Africa during March 2006. Atmos Chem Phys 9:7143-7160

40. Miller MA, Ghate VP, Zahn RK (2012) The radiation budget of the West African Sahel and its controls: a perspective from observations and global climate models. J Clim 25:5976-5996. https:// doi.org/10.1175/JCLI-D-11-00072.1

41. Collow ABM, Ghate VP, Miller MA, Trabachino L (2016) A one-year study of the diurnal cycle of meteorology, clouds, and radiation in the West African Sahel region. Q J R Meteorol Soc 142:16-29. https://doi.org/10.1002/qj.2623

42. Bonkaney A, Madougou S, Adamou R (2017) Impacts of cloud cover and dust on the performance of photovoltaic module in Niamey. J Renew Energy. https://doi.org/10.1155/2017/91075 02

43. Li F, Vogelmann AM, Ramanathan V (2004) Saharan dust aerosol radiative forcing measured from space. J Clim 17:2558-2571
44. Sawadogo W, Abiodun BJ, Okogbue EC (2019) Impact of global warming on photovoltaic power generation over West Africa. Renew Energy. https://doi.org/10.1016/j.renene.2019.11.032

45. Nielsen LB, Berkowicz R, Conradsen K, Prahm LP (1981) Net incoming radiation estimated from hourly global radiation and/ or cloud observations. J Climatol 1:255-272

46. Grist JP, Nicholson SE (2001) A study of the dynamic factors influencing the rainfall variability in the West African Sahel. J Clim 14:1337-1359

47. Afiesimama EA, Pal JS, Abiodun BJ, Gutowski, Adedoyin A, WJ Jr., Adedoyin A (2006) Simulation of West African monsoon using the RegCM3. Part I: model validation and inter-annual variability. Theor Appl Climatol 86:23-37. https://doi.org/10.1007/s0070 4-005-0202-8

48. Gbode IE, Adeyeri OE, Menang KP, Intsiful JDK, Ajayi VO, Omotosho JA, Akinsanola AA (2019) Observed changes in climate extremes in Nigeria. Meteorol Appl 26:642-654. https://doi. org/10.1002/met.1791

49. Odekunle TO (2004) Rainfall and the length of the growing season in Nigeria. Int J Climatol 24:467-479. https://doi. org/10.1002/joc.1012

50. Odekunle TO (2010) An assessment of the influence of the InterTropical Discontinuity on inter-annual rainfall characteristics in Nigeria. Geograph Res 48(3):314-326

51. Oguntunde PG, Abiodun BJ, Lischeid G (2011) Rainfall trends in Nigeria, 1901-2000. J Hydrol 411:207-218. https://doi. org/10.1016/j.jhydrol.2011.09.037

52. Abiodun BJ, Salami AT, Matthew OJ, Odedokun S (2012) Potential impacts of afforestation on climate change and extreme events in Nigeria. Clim Dyn 41:273-293. https://doi.org/10.1007/ s00382-012-1523-9

53. Rienecker MM, Suarez MJ, Gelaro R, Todling R, Bacmeister J, Liu E, Bosilovich MG, Schubert SD, Takacs L et al (2011) MERRA: NASA's modern-era retrospective analysis for research and applications. J Clim 24:3624-3648

54. Westberg DJ, Stackhouse PW Jr, Crawley DB, Hoell JM, Chandler WS, Zhang T (2013) An analysis of NASA's MERRA meteorological data to supplement observational data for calculation of climatic design conditions. ASHRAE Trans 119(2):210-221

55. Ohunakin OS, Adaramola MS, Oyewola OM, Matthew OJ, Fagbenle RO (2015) The effect of climate change on solar radiation in Nigeria. Sol Energy 116:272-286. https://doi.org/10.1016/j. solener.2015.03.027

56. Osinowo AA, Okogbue EC, Ogungbenro SB, Fashanu O (2015) Analysis of global solar irradiance over climatic zones in Nigeria for solar energy applications. Sol Energy. https://doi. org/10.1155/2015/819307

57. Zhang X, Lu N, Jiang H, Yao L (2020) Evaluation of reanalysis surface incident solar radiation data in China. Sci Rep 10:3494. https://doi.org/10.1038/s41598-020-60460-1

58. Tahir Z-uR, Ali MJ, Ahmad SU, Asim M, Hayat N, Azhar M, Hussain A (2018) Evaluation of solar radiation from MERRA, MERRA-2, ERA-Interim and CFSR reanalysis datasets against surface observations for Multan, Pakistan. EuroSun 2018/ISES Conference. https://doi.org/10.18086/eurosun2018.09.04

59. Salazar G, Gueymard C, Galdino JB, Vilela OC, Fraidenraich N (2020) Solar irradiance time series derived from high-quality measurements, satellite-based models, and reanalyses at a nearequatorial site in Brazil. Renew Sustain Energy Rev 117:109478. https://doi.org/10.1016/j.rser.2019.109478

60. Boilley A, Wald L (2015) Comparison between meteorological re-analyses from ERA-Interim and MERRA and measurements of daily solar irradiation at surface. Renew Energy 75:135-143. https://doi.org/10.1016/j.renene.2014.09.042

61. McNally A, Arsenault K, Kumar S, Shukla S, Peterson P, Wang S, Funk C, Peters-Lidard CD, Verdin JP (2017) Data descriptor: 
a land data assimilation system for sub-Saharan Africa food and water security applications. Sci Data 4:170012. https://doi. org/10.1038/sdata.2017.12

62. Ojo OS, Adeyemi B, Ogolo EO (2019) Assessment of the nighttime and daytime radiative fluxes balance on seasonal timescale over West Africa. J Atmos Sol Terres Phys 191:105048. https:// doi.org/10.1016/j.jastp.2019.05.012

63. Staley DO, Jurica GM (1972) Effective atmosphere emissivity under clear skies. J Appl Meteorol 11:349-356

64. Mihailovic DT, Kallos G (1997) A sensitivity study of a coupled soil-vegetation boundary-layer scheme for use in atmospheric modeling. Bound Layer Meteorol 82:283-315

65. Carmona F, Rivas R, Caselles V (2014) Estimation of daytime downward longwave radiation under clear and cloudy skies conditions over a sub-humid region. Theor Appl Climatol 115:281-295. https://doi.org/10.1007/s00704-013-0891-3

66. Al-Lami A, Al-Salihi AM, Al-Timimi YK (2017) Parameterization of the downward longwave radiation under clear-sky condtions in Baghdad, Iraq. Asian J Appl Sci 10:10-17

67. Fashae OA, Adagbasa EG, Olusola AO, Obateru RO (2020) Land use/land cover change and land surface temperature of Ibadan and environs, Nigeria. Environ Monit Assess 192:109. https://doi. org/10.1007/s10661-019-8054-3

68. Van de Griend AA, Owe M (1993) On the relationship between thermal emissivity and the normalised difference vegetation index for natural surface. Int J Remote Sens 14:1119-1131

69. Setturu B, Rajan KS, Ramachandra TV (2013) Land surface temperature responses to land use land cover dynamics. Geoinform Geostat 1:4. https://doi.org/10.4172/2327-4581.1000112

70. Allen RG, Pereira LS, Raes D, Smith M (1998) Crop evapotranspiration-guidelines for computing crop water requirements. Food and Agriculture Organization UN, Rome

71. Silva JB, Gaio DC, Curado LFA, Jde-S Nogueira, Valle LCG Jr., Rodrigues TR (2019) Evaluation of methods for estimating atmospheric emissivity in Mato-Grossense Cerrado. Revista Ambiente \& Água. https://doi.org/10.4136/ambi-agua.2288

72. Mann HB (1945) Non-parametric tests against trend. Econometrica 13:245-259

73. Kendall MG (1975) Rank correlation methods, 4th edn. Charles Griffin, London, p 202

74. Salmi T, Maatta A, Anttila P, Ruoho-Airola T, Amnell T (2002) Detecting trends of annual values of atmospheric pollutants by the Mann-Kendall Test and Sen's slope estimates. Publications on Air Quality, No. 31. Helsinki, Finland

75. Tosic I, Unkasevic M (2005) Analysis of precipitation series for Belgrade. Theor Appl Climatol 80(1):67-77

76. Alados I, Foyo-Moreno I, Olmo FJ, Alados-Arboleda L (2003) Relationship between net radiation and solar radiation for semi-arid shrub-land. Agric For Meteorol 116:221-227

77. Smith GL, Rutan DA (2003) The diurnal cycle of outgoing longwave radiation from earth radiation budget experiment measurements. J Atmos Sci 60:1529-1542
78. Kumar S, Srivastava AK, Pathak V, Bisht DS, Tiwari S (2019) Surface solar radiation and its association with aerosol characteristics at an urban station in the Indo-Gangetic Basin: implication to radiative effect. J Atmos Sol Terr Phys 193:105061. https://doi. org/10.1016/j.jastp.2019.105061

79. Ojo O (1977) The climates of West Africa. Heinemann, London, p 219

80. Hayward DF, Oguntoyinbo JS (1987) The climatology of West Africa. Rowan \& Littlefield, New York, p 271

81. Matzinger $N$, Andretta $M$, van Gorsel E, Vogt R, Ohmura A, Rotach MW (2003) Surface radiation budget in an Alpine valley. Q J R Meteor Soc 129:877-895

82. Augustine JA, Dutton EG (2013) Variability of the surface radiation budget over the United States from 1996 through 2011 from high-quality measurements. J Geophys Res Atmos 118:43-53

83. Kniffka A, Knippertz P, Fink AH (2019) The role of low-level clouds in the West African monsoon system. Atmos Chem Phys 19:1623-1647. https://doi.org/10.5194/acp-19-1623-2019

84. Matthew OJ, Ohunakin OS (2017) Simulating the effects of climate change and afforestation on wind power potential in Nigeria. Sustain Energy Technol Assess 22:41-54. https://doi. org/10.1016/j.seta.2017.05.009

85. Kothe S, Ahrens B (2010) On the radiation budget in regional climate simulations for West Africa. J Geophy Res Atmos 115:1984-2012

86. Stull RB (1988) An introduction to boundary layer meteorology. Kluwer Academic Publishers, Dordrecht, p 666

87. Wild $M$, Hakuba $M Z$, Folini $D$, Dörig-Ott $P$, Schär $C$, Kato S, Long CN (2018) The cloud-free global energy balance and inferred cloud radiative effects: an assessment based on direct observations and climate models. Clim Dyn 52:4787-4812. https://doi. org/10.1007/s00382-018-4413-y

88. Myers TA, Norris JR (2015) On the relationships between subtropical clouds and meteorology in observations and CMIP3 and CMIP5 models. J Clim 28:2945-2967. https://doi.org/10.1175/ JCLI-D-14-00475.1

89. Hill PG, Allan RP, Chiu JC, Stein THM (2016) A multi-satellite climatology of clouds, radiation and precipitation in southern West Africa and comparison to climate models. J Geophys Res Atmos 121(10):857-879. https://doi.org/10.1002/2016JD025246

Publisher's Note Springer Nature remains neutral with regard to jurisdictional claims in published maps and institutional affiliations. 